\title{
Toribia del Val y el misterioso caminante de Casas de Benítez ${ }^{1}$
}

\section{Toribia del Val and the Mysterious Wayfarer of Casas de Benítez}

William A. Christian Jr. Las Palmas de Gran Canaria

\section{RESUMEN}

La visión experimentada en 1931 por una mujer en su huerto de un pueblo de Cuenca durante una sequía demuestra la pervivencia, en vísperas de la Guerra Civil española, de la idea de un forastero o peregrino misterioso que aparece con instrucciones para el pueblo, una antigua manera de proponer soluciones celestiales a problemas colectivos.

Palabras clave: Visiones, Peregrinos, Ángeles, Sequía, Rogativas, Castilla-La Mancha.

\section{SUMMARY}

The vision of a woman in her garden during a drought in a village in the Spanish province of Cuenca in 1931 suggests the vitality of old stories and the survival at the eve of the Spanish Civil War of the idea of a mysterious stranger or pilgrim, an old way of introducing heaven's solutions to group problems.

Key words: Visions, Pilgrims, Angels, Strangers, Drought, Rain Processions, CastillaLa Mancha.

${ }^{1}$ Doy las gracias a Marilina Maroto, Marisol Llamas García y Diego Ramón Martínez, de Casas de Benítez, al Rvdo. Miguel Ruiz Orozco, párroco de Vara del Rey, a Mercedes Gómez, Elena del Castillo y Vanesa Blanco Gallardo, de Burguillos, así como a Mónica Cornejo Valle, que me acompañaron allí. María José del Río me aconsejó desde el principio sobre este proyecto y me proporcionó un espacio en la UAM para abordarlo. Pascual Martínez Martínez me ayudó generosamente con fuentes sobre Casas de Benítez y en la propia localidad, y Miguel Ángel Muñoz Torres me puso en contacto con sus parientes del pueblo y me llevó a él. José Luis Gil Aristu, amigo leal, ha sido otra vez fiel y sugerente traductor. Entre quienes me ayudaron en materia de logística, ilustraciones y sugerencias se hallan James Amelang, Silvia Arrom, Lisa Bitel, María Cruz de Carlos, Cristina García Rodero, Pedro Gila García, Byron Hamann, Dorothy Noyes, José Manuel Pedrosa, Felipe Pereda, Éva Pócs, Joan Prat, María Tausiet y William Taylor. 
Un no-evento en Casas de Benítez (Cuenca), mayo de 1931

Las continuidades entre el presente y el pasado son especialmente llamativas en asuntos religiosos, algunas de cuyas instituciones tienen más de mil años de existencia. Ciertas prácticas, como el recurso a ofrendas o sacrificios votivos, y algunos tipos de lugares sagrados, como fuentes, grutas, árboles descollantes o cimas de montañas, preceden, incluso, en el tiempo a las religiones particulares en las que cumplen una función en el presente. Estas continuidades tipológicas han servido de distintas maneras como pretexto para descalificar o relativizar la fe, postular una espiritualidad transcultural o aportar un pedigrí a ritos nuevos y sustitutorios (Fedele 2007). En algunas religiones hay lugares sacros, imágenes de santuarios, reliquias y manuscritos sagrados particulares de los que se ha hecho uso durante más tiempo que el que lleva existiendo cualquier Estado nacional de nuestros días. Otras prácticas, como las de las procesiones para impetrar lluvia y los exorcismos, siguen siendo sorprendentemente similares desde hace siglos.

La medievalista Lisa Bitel y el fotógrafo Matt Gainer asistieron a lo largo de varios años a las visiones mensuales de María Paula Acuña, una quincuagenaria, madre de seis hijos, en el desierto de Mojave, en California. Yo acudí con estudiantes en un par de ocasiones. Lo habitual solía ser que cientos de peregrinos latinoamericanos esperaran a que María Paula y las mujeres que la acompañaban llegasen en una furgoneta. Una procesión a pie se detenía y la gente tomaba fotos del cielo cuando María Paula tenía su visión de Nuestra Señora de las Rocas. Luego, en el lugar de culto, la vidente informaba sobre el mensaje de la Virgen y pronunciaba una homilía de carácter más general, aceptaba preguntas y bendecía individualmente a los peregrinos. Estos hechos han estado ocurriendo durante casi veinte años, con menciones intermitentes en prensa y televisión. Pero cuando, en 2008, Bitel llamó por teléfono a la diócesis de Fresno, un portavoz desechó las visiones considerándolas un "non-event" (suceso no sucedido) (Bitel, comunicación personal, 1998; Bitel y Gainer 2009). Un gran número de esta clase de visiones "no sucedidas", episodios no registrados, no reconocidos, fútiles, no entran a formar parte de la historia.

Una búsqueda en periódicos históricos realizada en el verano de 2009 por medio de Internet sacó a la luz el relato de una visión religiosa publicado en la República, un semanario de centro izquierda de la ciudad de Cuenca. El artículo está fechado el 26 de octubre de 1931, a los seis meses de que España se convirtiera en una república y unos días después de que las Cortes votaran a favor de la separación entre Iglesia y Estado. Durante al menos treinta años, España había estado profundamente dividida entre 
creyentes y no creyentes, que se mostraban más militantes que nunca. En aquellos primeros meses, la prensa —en unos casos maravillada, y en otros despectiva- había publicado reportajes sobre apariciones de la Virgen María en Ezkioga, un pueblo del País Vasco, así como en otros lugares². En agosto, por ejemplo, la República se había referido a “...los retrasados mentales que aún creen en 'las apariciones' y esperan el milagro ... [como] la reata que sigue a los intrigantes clericales ...[después de] tantos siglos de superstición y servidumbre..." (Giménez de Aguilar 193133). Tres meses más tarde, el redactor se enteró desconcertado de que en un remoto rincón de su propia provincia se había producido una aparición a principios de añó .

¿También en Cuenca?

Sí señores, sí; también en Cuenca ha habido apariciones. En un pueblecito de la Mancha, Casas de Benítez, y en ocasión de hallarse cogiendo habas, Toribia "La Vaquera" —cuentan unos señores naturales de dicho pueblo- al levantar la cabeza, encontróse con la mirada humilde, suplicante y un poco conmiserativa de un Señor con toda la barba que le pidió un puñado de habas. Apresuróse la susodicha vidente a cogerlas, solicitando entonces el aparecido se las diese de las que llevaba cogidas en el mandil. Hízolo así, al mismo tiempo que se lamentaba de la pertinaz sequía. El aparecido, un tanto compasivo, enarcó las cejas, abrió desmesuradamente los ojos, y díjole:

-Esa sequía es porque quieren. Saquen en procesión a San Isidro de Casas de Benítez y, con la Virgen de la Cabeza de Pozo Amargo, los unen en el sitio llamado La Poza, y las cataratas del Niágara serán una simple regadera comparadas con lo que va a caer.

Dicho esto, y antes de que reaccionara "La Vaquera" del asombro, desapareció... Sin duda, la buena señora se dio tal arte para convencer a las autoridades, de ambos pueblos, que, a pesar de ser republicanas —esto era después del 14 de abril-, allá que van ambos santos en procesión, acompañados de unas cinco mil personas llegadas de Sisante, La Roda, Casas de Haro, Casas de Guijarro y aledaños, provistas todas de sus correspondientes paraguas en busca del milagro. Pero, ¡oh ironías del destino! El cielo, que amaneció nublado aquel día, dando lugar a que saboreasen los más creyentes el pseudo milagro, apenas llegada la hora em-

${ }^{2}$ Los otros lugares de visiones aparecidos en la prensa nacional entre julio y el 26 de octubre de 1931, aparte de los numerosos de Gipuzkoa, Álava y Navarra asociados con Ezkioga, son Rielves (Toledo) y Guadamur (Toledo), en agosto, y Órgiva (Granada), Guadalajara y Sigüenza, en septiembre (Christian 2011: cap. 7).

${ }^{3}$ El 17 de agosto, también en la República, Mandrágora (1931) aludía de manera similar a las "inferioridades mentales", y el poeta León de Huelves Crespo, en una charla pronunciada en Villarrubia de Santiago con ocasión de un mitin de los radicales socialistas, declaró: "En nuestra república debemos evitar que haya mentirosos que inventen milagros e imbéciles que los crean" (La Libertad [Madrid], 17 de noviembre de 1931, 10).

${ }^{4}$ República [Cuenca], 26 de octubre de 1931, 1 [en la sección "Martillazos", firmado por "La Redacción"]. 
pezó a despejarse de tal forma que la vuelta hubo de hacerse bajo el paraguas por miedo... a las inclemencias de Febo que sonreía satisfecho de su burla.

Casas de Benítez, una localidad agrícola de 1.500 habitantes en aquel momento, se halla situada en el límite meridional de la provincia. Las noticias del pueblo eran raras en la prensa conquense. El semanario publicó esa nota en el contexto de la nueva república y sólo lo hizo después de que las apariciones en general se convirtieran en pasto de ridiculización, tras un lapso de cinco meses, y únicamente —deberíamos añadir- porque no llovió. Si la anécdota llegó a publicarse en 1931 y se halla hoy a nuestra disposición es por chiripa 5 .

¿Existió realmente una tal Toribia que dijo haber tenido una visión? ¿Se celebraron realmente las procesiones? Sí existió, y sí se celebraron. Un amigo madrileño tenía una prima en Casas de Benítez; este amigo mío la llamó, y ella a su vez localizó a una nieta de Toribia, Marisol Llamas, que tiene ahora 60 años. La historia que Marisol me contó por teléfono fue la que le habían relatado su madre y su hermana mayor ${ }^{6}$ :

La abuela Toribia era mucho de misa, aunque no beata... Creía mucho en Dios. No tenía estudios (mi madre y mi padre tampoco). A la abuela Toribia se le apareció como si fuera Dios ${ }^{7}$, con barbas y pelo largo, y había tanta sequía, y el de las barbas dijo que sacaran a San Isidro y Santa María de la Cabeza, que llovería. Y se subió una ventisca, y entonces empezó a llover. [Voz de un vecino: "Pero no llovió ni nada"].

Según Marisol, la familia estaba de acuerdo en que el aparecido era Cristo, pero se trataba de una cuestión no resuelta. Le pregunté si el forastero que pidió las habas pudo haber sido san Isidro, que suele tener barba y pelo largo. Marisol, sin embargo, respondió con prontitud y firmeza: "Pero tenía el pelo largo, y el san Isidro lo lleva recogido".

En febrero de 2010, mi amigo Miguel, su prima Marilina y yo visitamos a Marisol y a su marido, jubilados en Casas de Benítez tras haber trabajado en Madrid, Alemania y Cataluña. Marisol volvió a relatarnos la historia mien-

${ }^{5} \mathrm{Y}$ es accesible porque el Centro de Estudios de Castilla-La Mancha ofrece los periódicos históricos regionales en Internet, en formato PDF, con posibilidad de búsqueda mediante palabras clave.

${ }^{6}$ Conversación telefónica con Marisol Llamas García (n. 1939), Casas de Benítez.

7 Cuando le pedí que lo aclarara, no describió la figura de Dios Padre sino la de Cristo.

${ }^{8}$ Le pregunté si se trataba de un Cristo vestido de un color determinado, como el Nazareno de ropajes de púrpura que porta la cruz en la cercana población de Sisante, cuyo santuario es visitado por personas de Casas de Benítez que acuden a ofrecer votos, pero Marisol no tenía ninguna idea acerca de su atuendo ni de si llevaba una cruz. 
tras tomábamos un café con bizcocho. Luego, marchamos todos en coche hasta la zona situada a medio camino entre Casas de Benítez y Pozoamargo, lugar de encuentro de las procesiones. (fig. 1).

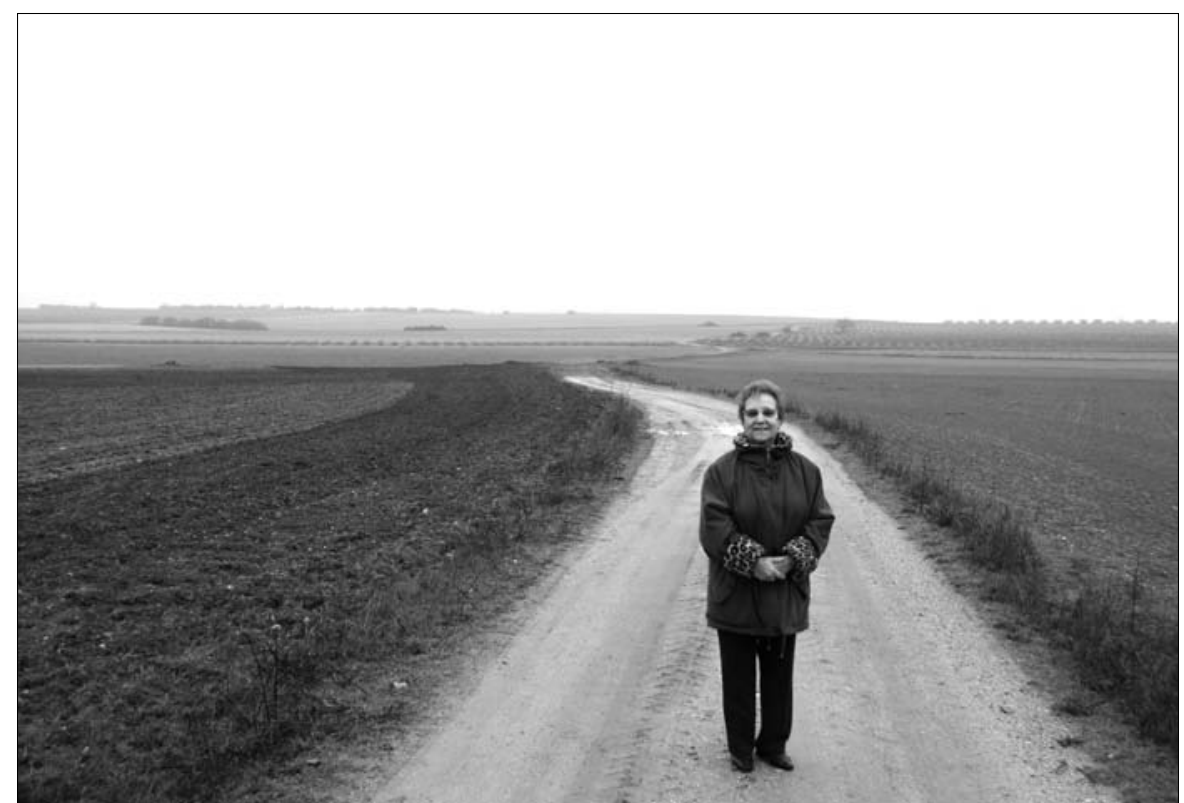

FIg. 1. Marisol Llamas, nieta de Toribia del Val, en La Poza, lugar del encuentro de las procesiones rogativas, Casas de Benítez (Cuenca), el 8 de febrero de 2010. Foto: autor. Con permiso de Marisol Llamas.

Más adelante hablé por teléfono con dos ancianos que habían participado en las procesiones siendo niños. Estaban seguros de que, aunque mucha gente llevaba paraguas, no había llovido cuando las imágenes se encontraron. Uno dijo que el día de la procesión había granizado algo en otros pueblos, pero el granizo no había afectado a Casas de Benítez? . El otro recordaba que habían cantado himnos durante la procesión, que había lloviznado un poco cuando salían de la localidad y que un hombre apellidado Mingarro vendía agua gaseosa desde un carro $^{10}$. El cronista extraoficial de la localidad es Pascual Martínez, ingeniero nuclear retirado que reside actualmente en Madrid. Él fue quien me dirigió hacia esos dos hombres y

9 Conversación telefónica del 9 de febrero de 2010 con José Toledo Ortiz (n. el 15 de septiembre de 1920), Casas de Benítez.

${ }^{10}$ Conversación telefónica del 9 de febrero de 2010 con Honorato García (n. el 16 de mayo de 1920), Madrid. 
quien llamó por mí a una mujer de Casas de Benítez que en mayo de 1931 debía de tener ocho años y se acordaba de que, cuando las dos imágenes se encontraron, se había celebrado una misa y su padre la había aupado sobre sus hombros para que pudiese ver al sacerdote ${ }^{11}$. El propio Martínez describe la procesión en uno de sus libros basándose en entrevistas realizadas en la década de 1970. Sus informantes se acordaron de los versos cantados para impetrar lluvia y contaron que era un día caluroso de mayo, que el sacerdote de Pozoamargo pronunció un sermón cuando las procesiones se juntaron y que no llovió; pero nadie le había mencionado la visión de Toribia (Martínez 1996: 115-116) ${ }^{12}$.

Uno de los hombres con quienes hablé dijo tener una vaga idea de que Toribia tenía algo que ver, mientras que el otro comentó: "Toribia decía que había visto la Virgen de la Cabeza, y fue ella la que organizó la procesión"13. La mujer, que resultó ser la viuda de uno de los nietos de Toribia, se mostró precisa sobre lo impreciso de la visión" ${ }^{14}$ : "Toribia cultivó una huerta con tomates y habas muy cerca del pueblo, en el Camino de San Clemente. Allí se le apareció un hombre, no se sabe si Dios, Cristo [o] un ángel. Era cuando Toribia estaba cogiendo habas. Fue la comidilla del pueblo".

Toribia del Val tenía 63 años en el momento de su visión ${ }^{15}$. Ella, su marido y sus hijos habían sido llevados al pueblo cuando eran una familia joven para encargarse del ganado del mayor terrateniente de la localidad, un hombre emprendedor que dirigía las centrales hidroeléctricas de la región. El marido de Toribia era uno de los cientos de empleados o jornaleros del terrateniente, y su familia estaba lejos del centro de poder de la localidad ${ }^{16}$.

Aunque había cierto desacuerdo sobre el lugar donde se encontraron las procesiones, la gente de Casas de Benítez y Pozoamargo coincide en que

${ }^{11}$ Salud Toledano Serrano, de 87 años, Casas de Benítez, en conversación telefónica con Pascual Martínez el 21 de febrero de 2010.

${ }^{12}$ En las actas del ayuntamiento de Casas de Benítez no se menciona la procesión, y el archivo parroquial fue quemado durante la Guerra Civil. El párroco de Pozoamargo, Miguel Ruiz Orozco, no halló mención en el registro parroquial de la localidad (comunicación personal, 3 de octubre de 2010).

${ }^{13}$ José Toledo Ortiz, 9 de febrero de 2010.

${ }^{14}$ Salud Toledano Serrano, 21 de febrero de 2010.

${ }^{15}$ Casas de Benítez, Archivo Municipal, 1932, lista de votantes; según el registro civil, Toribia falleció de un ataque al corazón en 1938 a los 68 años de edad. Por cortesía de Pascual Martínez.

${ }^{16}$ Comunicaciones personales de Marisol Llamas y Pascual Martínez. El negocio sigue existiendo, y lo lleva, a sus 90 años, el nieto de su antiguo propietario, pero la empresa no conserva un registro de los empleados de la década de 1930, muchos de los cuales sólo tendrían, en cualquier caso, contratos verbales. 
la reunión se produjo, efectivamente, en la zona conocida como La Poza ${ }^{17}$. Todos situaron los sucesos a finales de abril o en mayo, pues sólo entonces se hallaban las habas en sazón, y ése era el momento en que se habría necesitado lluvia para otros cultivos. Así pues, la visión debió de haberse producido en una fecha próxima al 15 de mayo, festividad de san Isidro, cuando era costumbre comer habas crudas con tiras de bacalao salado durante las corridas de toros.

En cierto sentido, los habitantes de Casas de Benítez y los pueblos circundantes debieron de haber estado preparados para la visión por una experiencia traumática vivida en mayo de 1929, cuando, en quince minutos, una intensa granizada con un estrépito de motor de avión destruyó por completo los cultivos de la localidad. Si dos años después, durante la procesión de Toribia, cayó granizo en otro lugar sin afectar a Casas de Benítez, el resultado no habría sido tan malo, aunque apenas respondió a lo prometido $^{18}$.

El suceso "no sucedido" de 1931 se produjo también en una fecha cercana a la de la proclamación de la república, el 14 de abril, y a la de la quema de iglesias en Madrid, Málaga y otras ciudades por alborotadores

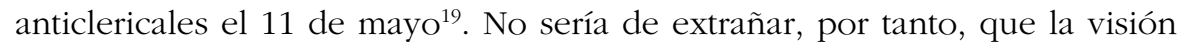
de Toribia o la reacción de las dos localidades ante dicha visión tuvieran una faceta política. Una procesión para obtener lluvia celebrada la semana anterior al 16 de mayo en el pueblo de Quero, a 120 kilómetros al oeste, se dirigió a la Virgen María no sólo "para impetrar de su intercesión la lluvia benéfica para los agostados campos", sino también suplicando "su mediación para el bien de la Iglesia y de España”. Y durante las rogativas celebradas en Quero se produjeron las curaciones milagrosas de un hombre doblado por la artrosis y de una mujer con grandes dolores por la rotura de un tobillo ${ }^{20}$. A comienzos de mayo, la gente invadía cotos de caza en

\footnotetext{
${ }^{17}$ Más en concreto, en un lugar conocido como Las Periconas.

${ }^{18} \mathrm{El} \mathrm{Sol}$ (Madrid), 30 de mayo de 1929, 6, "Estragos de la tormenta", escrito por un periodista que visitó Casas de Benítez ("todo el término de este pueblo ha quedado destrozado") y los pueblos circundantes.

${ }^{19}$ Ver una descripción republicana de los temores suscitados supuestamente por el clero en las elecciones municipales de abril en Martínez Pérez (1931); y sobre la satisfacción de republicanos de localidades cercanas por las quemas de iglesias en Madrid el 11 de mayo, ver la caricatura y el poema de Rafael Alcázar Manzanares en la página 3 de Amanecer [Tarancón], 1 de junio de 1931.

${ }^{20}$ El Corresponsal, "Quero.-Casos prodigiosos", El Castellano [Toledo], 16 de mayo de 1931, 2. De manera similar, algún tiempo antes de 1925, una mujer tullida fue curada tras insistir en que la llevaran a una rogativa de la Virgen de la Salud en Borox, según El Castellano, 25 de mayo de 1925, 3.
} 
diversas partes de Castilla la Nueva para arar la tierra y cazar. Jornaleros y maestros de escuela, por un lado, y terratenientes, por otro, formaron en muchas localidades partidos políticos republicanos enfrentados. En Casas de Benítez, el nuevo ayuntamiento fue elegido de una lista expresamente no partidista, pero en los meses siguientes hubo estallidos de violencia en pueblos vecinos, y en Casas de Benítez algunos socialistas plantearon peticiones al ayuntamiento ${ }^{21}$. En gran parte del país, el sentimiento de esperanza revolucionaria entre los pobres y los intelectuales tuvo como contrapunto otro de expectante epifanía entre los católicos. En abril, mayo y junio, la prensa del norte de España ofreció informaciones sobre apariciones de la Virgen en Mendigorría (Navarra) y Torralba de Aragón (Huesca) (Christian 2011: 30-32).

Un aspecto notable de los recuerdos de las personas con quienes hablé fue la naturalidad con que se tomaron la visión de Toribia. Nadie se molestó en mencionarla a Pascual Martínez, mientras que la procesión sí constituyó una memorable ruptura con la rutina cotidiana sobre la que valía la pena informarle. Aunque en 1931 los grados de escepticismo de la gente del pueblo fueron, seguramente, diversos, algunos pensaban que Toribia era un tanto especial debido a su visión. Dos de las personas con las que hablé recordaban cómo cada año, por Pascua, repartía tortas planas y redondas sin levadura a quienes salían de la iglesia. Se trataba de una caridad - una costumbre que se remontaba a la Edad Media y que pervive todavía en esa zona en algunas festividades como consecuencia, generalmente, de ciertos votos ofrecidos por todo el pueblo-. Al parecer, Toribia hizo su

${ }^{21}$ Según la República (25 de mayo de 1931, 3), con motivo de un entusiástico mitin electoral celebrado el 12 de mayo, la cercana localidad de Vara del Rey "era en su totalidad republicana". Las actas del ayuntamiento de Casas de Benítez del 17 de abril de 1931 decían —dato que agradezco a Pascual Martínez-: "Los señores nombrados fueron elegidos en elección popular sin matiz alguno político por voluntad del pueblo". Según Martínez, la mayoría eran católicos convencidos. El alcalde anterior a la República, José María Ruiz Ballesteros, permaneció como segundo teniente de alcalde, y volvió a ser alcalde el 15 de agosto de 1931. El 23 de agosto, el ayuntamiento negó por unanimidad una petición del director de la socialista Casa del Pueblo para que se creara una comisión independiente a fin de examinar los gastos municipales durante la dictadura, de 1923 a 1931. El ayuntamiento presentó supuestamente los libros de cuentas a examen público a partir del 10 de agosto y los aprobó el 28 del mismo mes. A finales de julio de 1931, hubo enfrentamientos políticos entre dos partidos republicanos en la cercana localidad de Villagordo del Júcar, entre ellos un desfile carnavalesco de mujeres y niños que llevaban en un carro de reparto de pan a dos hombres que tocaban un acordeón y una guitarra; el desfile terminó con la intervención de la guardia civil y un muerto por arma de fuego (Diario de Albacete, 29 de julio, 1; 30 de julio, 1). Ver también Martínez (1982). 
propio voto de repartir las tortas a raíz de su visión. Al menos una familia reservó la torta de Toribia para utilizarla contra el mal de ojo, especialmente para proteger a sus niños ${ }^{22}$.

¿Qué es lo que hace de esta historia, mero esqueleto de un relato, un caso interesante?

Una de las razones es que se trata de una historia desaparecida, y todos - historiadores o no-, tenemos que enfrentarnos a la cuestión fundamental de saber cuánto es lo que no se nos ha contado. Pascual Martínez piensa que la gente no le mencionó la visión de Toribia, sencillamente, porque él no se lo preguntó y ellos no la consideraban importante. De no haber sido por aquel suelto de prensa olvidado desde hace tanto tiempo, Toribia y su visitante no habrían entrado a formar parte de un informe escrito, pues se trataba de un suceso no sucedido para todas las personas de Casas de Benítez con las que hablé.

Por la misma razón es muy posible que muchos contactos extraordinarios con lo sobrenatural - la mayoría, probablemente- no hayan sido documentados y se hayan quedado en el ámbito personal, familiar o vecinal. De no haber sido por una improbable conjunción de factores, y en particular por las relevantes noticias acerca de las apariciones de Ezkioga, tampoco ésta habría llegado a publicarse nunca. Así pues, constituye un precioso ejemplo del cúmulo de historias sobre apariciones y sobre rogativas para impetrar lluvia que no han sido relatadas, y de aquellos aspectos de las historias no narradas que las hacen carecer de interés informativo (Christian 2009b).

Para empezar, Toribia no tenía pruebas de su visión. Las visiones requieren, por definición, una demostración especial para ser creídas. En la España medieval era característico que entre esa clase de pruebas se incluyera algún tipo de marca o anomalía corporal: una mano pegada a la mejilla, una boca que no podía abrirse por la fuerza, o la presencia de alguna prenda procedente del otro mundo. A partir del siglo XVI, cuando la Inquisición empezó a mirar mal a los videntes, las pruebas fueron las propias imágenes, que sudaban o sangraban de manera visible para todos. En las apariciones modernas, a partir de La Salette, las señales fueron de diversos tipos: estados similares al trance en los que los videntes eran, al parecer, insensibles a quemaduras o pinchazos; una aparente transmisión del conocimiento de lenguas como el arameo o el latín; la demostración de las visiones mediante anomalías celestes - movimientos giratorios del Sol y halos en torno a él, o representaciones por medio de nubes, como, por ejemplo, cruces en el cielo-. Y en todas las épocas, esas señales podían ser algún

\footnotetext{
${ }^{22}$ Entrevista telefónica con Marisol Llamas, 8 de noviembre de 2010.
} 
medio para provocar curaciones súbitas y milagrosas, como un manantial terapéutico recién descubierto. En el caso de Toribia, la señal habría sido la lluvia que no se produjo; y su visión es representativa, en particular, de aquellas de las que nunca oiremos hablar por haber carecido de confirmación.

\section{ROGATIVAS PARA PEDIR LLUVIA}

De la misma manera que su visión no fue confirmada, también la procesión para pedir la lluvia respondió a un procedimiento nuevo que resultó ineficaz. Las rogativas para pedir lluvia tenían sus oraciones especiales, itinerarios locales tradicionales, protocolos e himnos impetratorios. Toribia o su visitante intentaron introducir una innovación en los procedimientos locales haciendo que se juntaran imágenes y procesiones de dos localidades.

La elección de las imágenes fue importante, pues aunque la gente tendía a confundirla con la Virgen de la Cabeza - advocación de la Virgen María-, la patrona de Pozoamargo era santa María de la Cabeza, esposa de san Isidro. Isidro Labrador vivió en la región de Madrid en el siglo XIII, y su canonización, ocurrida en 1622, fue una confirmación del nuevo poder de Madrid como capital de la corte española. A partir de ese momento, el culto a Isidro y su esposa se difundió por toda España, complementando o sustituyendo a otros santos especialistas en el ámbito de la agricultura. (Del Río 2000: 93-118; Roig Torrentó 1988). En cierto modo, tenía su lógica unir a marido y mujer, separados en poblaciones vecinas, para abrir las compuertas del cielo.

La unión de seres sobrenaturales masculinos y femeninos contaba con una larga historia en España, en Castilla la Nueva e, incluso, en Casas de Benítez, donde el momento más dramático de la Semana Santa era el del "Encuentro" de la imagen de Cristo con la de María en las calles del pueblo. En la mayoría de las localidades, el encuentro tiene lugar en la plaza el día de Viernes Santo, cuando Cristo carga con la cruz. En Casas de Benítez se efectuaba a las tres de la mañana del día de Pascua, con Cristo resucitado.

En las rogativas españolas interviene a menudo, aunque no siempre, un personaje femenino, generalmente la Virgen María, y Cristo o un santo masculino. El procedimiento habitual consistía, en muchos lugares, en sacar de un santuario una imagen poderosa de María o de santa Ana y colocarla en el altar mayor de la iglesia parroquial, "junto al sagrario", según explicitaba una descripción de 1578, para que la imagen intercediera ante Dios en favor de la comunidad (Zarco Cuevas 1983: 222)²3. En Badajoz se solía llevar

\footnotetext{
${ }^{23}$ Carrascosa del Campo, imagen de santa Ana.
} 
a la Virgen de Botoa desde su santuario rural y colocarla delante de san José, copatrón de la ciudad, juntando así a esposo y esposa, como en Casas de Benítez (Marcos Arévalo y Borrego Vázquez 2006). De manera similar, en una localidad a doscientos kilómetros al suroeste de Casas de Benítez se sigue sacando todos los años a san José el 8 de mayo para que se reúna con la Virgen del Rosario, llevada desde otro pueblo. Las dos procesiones se juntan con el agua hasta la rodilla en un río que marca el límite entre ambas poblaciones ${ }^{24}$. Por tanto, la innovación solicitada por Toribia no era tan extravagante. (fig. 2).

La idea de reunir imágenes de distintas localidades no tiene tampoco, por supuesto, nada de excepcional ${ }^{25}$. A lo largo y ancho de España hay santuarios a donde los pueblos llevan sus imágenes en determinados días y

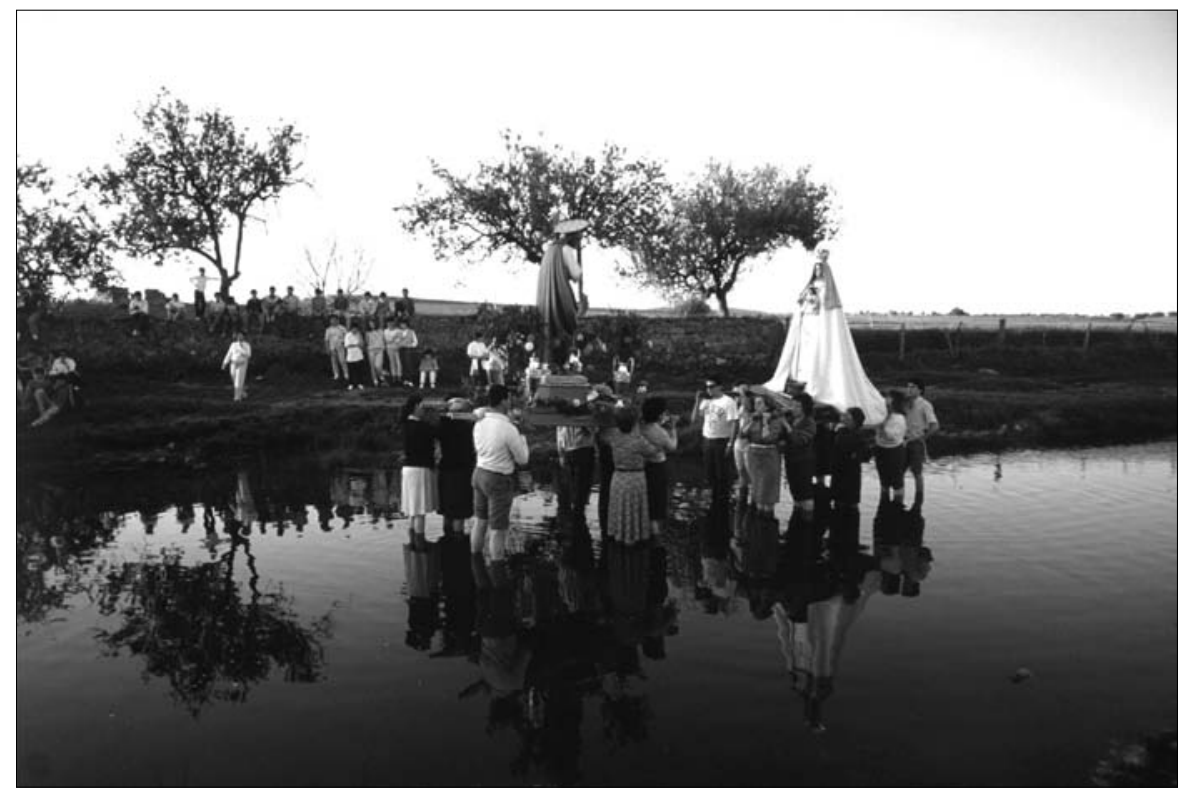

Fig. 2. Nuestra Señora del Rosario y San José se encuentran en el río, Villamayor de Calatrava y Tirteafuera (Ciudad Real), el 1 de mayo 1984. Foto: Cristina García Rodero. Con permiso.

${ }^{24}$ La costumbre anual data, por lo menos, de hace 50 años y pudo haber tenido su origen en una procesión para impetrar lluvia designada con el término "rogativa".

${ }^{25}$ Algunos pueblos de la archidiócesis de Toledo llevaron sus imágenes a la capital toledana durante el año mariano de 1954. El caso más espectacular de la diócesis de Cuenca fue la concentración de imágenes especiales de cada localidad, entre ellas las de San Isidro, de Casas de Benítez, y Santa María de la Cabeza, de Pozoamargo, para la coronación canónica de una imagen de la Virgen María de la ciudad de Cuenca (Álvarez Chirveches 1957). 
en algunos las imágenes se saludan y despiden ritualmente (Christian 1991: 148; Lisón Tolosana 1976) ${ }^{26}$. La confluencia de procesiones de distintos pueblos para impetrar lluvia tiene igualmente una larga tradición, en particular en zonas donde hay una escasez crónica de precipitaciones y en las que docenas de pueblos se reúnen en un santuario u otro ${ }^{27}$.

Aunque las visiones y rogativas fallidas no solían ser noticia, el periódico republicano de Cuenca tenía interés en hacer hincapié en el fracaso. Las procesiones para pedir lluvia habían sido, al menos durante los treinta años anteriores, una demostración del poder divino para los católicos, y un motivo de ridículo para los librepensadores ${ }^{28}$. En julio, la República había publicado ya en primera página un poema satírico sobre el fracaso de unas insistentes plegarias en demanda de lluvia en otro pueblo de Cuenca. Lo que acabó cayendo no fue agua, sino una granizada que arruinó las cosechas, y, según se decía, algunos lugareños intentaron destruir la imagen del Cristo responsable de aquel hecho ${ }^{29}$. La procesión de Casas de Benítez y

\footnotetext{
${ }^{26}$ Sobre Achas, ver fotografías de Cristina García Rodero.

27 Nocito (Huesca) y Valtablado del Río (Guadalajara) (Christian 1991: 149); Bellpuig de Urgel (Gelabertó Vilagrán 2005: 199).

${ }^{28}$ Dorothy Noyes (comunicación personal) propone como ejemplos "Deu-nos aigua, majestat!" (1906), de Raimon Casellas, y la comedia de Joan Puig i Ferreter, "Aiguas encantades" (estrenada en 1908).

${ }^{29}$ República, 13 de julio de 1931, 1:

Un cura sin influencia
"iOh Cristo de la Salud,
hijo del Verbo bendito!
Échanos un poco de agua
que, por aquí, estamos fritos.
Esto Henarejos te pide
con toda su devoción,
y aunque llegue hasta los huesos
danos un gran remojón”.
Y así, un día y otro día,
el buen capellán clamaba
para remozar los campos
que, abrasados, se secaban.
El Cielo oyó los clamores
de tan terco interceder,
y un pedrisco asoló todo,
sin dejar con qué encender.
E indignados los del pueblo,
con sigilo, y sin hablar,
al Santo Cristo bendito
lo quisieron estrellar.
(Histórico)
}


Pozoamargo estuvo especialmente expuesta a la decepción y el ridículo debido a que el forastero había predicho un aguacero que se produciría en determinado momento y lugar.

Aquella expectativa no constituía un caso normal. A lo largo de la historia, las poblaciones habían practicado ante la sequía una serie graduada de reacciones que comenzaban con oraciones y procesiones en la iglesia o la catedral, la exhibición de reliquias o imágenes para ser veneradas, el traslado de imágenes de una iglesia (a menudo un santuario rural) a otra (la iglesia parroquial o la catedral) para una estancia de nueve días, y el encuentro entre dos imágenes. En algunos lugares de la España de la Edad Moderna, las imágenes se sumergían en manantiales, arroyos o ríos. Y, si la sequía persistía, se realizaban en todas partes prácticas progresivamente crecientes de penitencia pública. En esta serie gradual, algunas peticiones se hacían una y otra vez; se trataba, sencillamente, de rezar, de rogar a diferentes santos o de de hacerlo con mayor fervor, hasta que la sequía terminaba (Faci 1979: passim; Cortés Peña 1995a, 1995b; López 1989; Peris Albentosa 2009; Romeu Figueras 1951; Sáez de Ocáriz 1990; Zamora Pastor 2000; Kamen 1993: 36-39, 180-181) ${ }^{30}$.

En noticias sobre estas procesiones recogidas en crónicas de pueblos y ciudades, como las de Sevilla y Barcelona, se mencionan de pasada casos fallidos, pues los fracasos formaban parte de un diagnóstico seriado mediante pruebas de ensayo y error destinadas a identificar al santo deseoso de ayudar a la localidad, y que llevaban de manera característica a prescindir de unos santos especializados de menor rango para recurrir a otras imágenes más importantes y, en general, más poderosas. Cuando todo lo demás fallaba, se solía probar con santos ignorados u olvidados hasta entonces y la población adoptaba un comportamiento penitencial más extremado y un despliegue de demostraciones emotivas. La cuestión no era si las plegarias acabarían por tener resultado, sino qué santos y qué prácticas penitenciales concomitantes demostrarían ser eficaces. El descubrimiento de un santo inesperado cuya intercesión había desembocado en una lluvia espectacular podía llevar a la formulación de un nuevo voto que se cumpliría en la festividad del santo o el día en que éste provocó la lluvia ${ }^{31}$.

${ }^{30}$ Ver en Gelabertó Vilagrán (2005: 190-202) ejemplos de la casuística de los predicadores cuando las procesiones para impetrar lluvia resultaban infructuosas en la Cataluña del siglo XVIII.

${ }^{31}$ Las "relaciones topográficas" de Felipe II (1575-1580) preguntaban por los motivos de los votos locales; alrededor de un $4 \%$ de aquellos para los que se cita una razón recordada se habían hecho para impetrar lluvia (Christian 1991: 45, 62-3). 
Las propias procesiones podían estar cargadas de emoción. Durante la Edad Moderna, en las procesiones para impetrar lluvia, se produjeron milagros como los ocurridos en Quero en 1931. Estos milagros se interpretaban como efectos colaterales de la oración y la penitencia colectivas, que ablandaban el corazón de los seres divinos. En un compendio sobre santuarios de Aragón realizado en el siglo XVIII (Faci, reimpresión de 1979) se recogen varios ejemplos. En 1703, durante una procesión celebrada en Fraga para devolver una imagen de Cristo a Torrente, pareció que se multiplicaban las hogazas de pan distribuidas entre los participantes (t. 1: 131). En 1710, una mujer agonizante resultó curada al pasar delante de ella una imagen de la Virgen María que era llevada a Belchite (t. 2: 25). En 1713, un soldado protestante se convirtió tras haber visto los resultados de unas rogativas para impetrar lluvia en un santuario mariano de Uncastillo (t. 2: 522). En 1737, una mujer ciega recuperó la vista cuando una imagen de la Virgen María regresaba a su santuario desde Ariño (t. 2: 67). En Hecho no hubo ningún herido tras hundirse un puente inmediatamente después de que lo cruzara una procesión con una imagen de la Virgen; y a continuación, cuando la imagen llegó a la iglesia del pueblo, cayó un aguacero (t. 2: 481) 32. Y en Tarazona, en la década de 1730, cuando el crucifijo de los franciscanos se transportaba en rogativa, "pone la devoción a los niños quebrados en medio en las calles, y quedan curados muchos, al passar sobre ellos la S. Imagen assí venerada" (t. 1: 108). En la España de la Edad Moderna, las rogativas eran también algunas de las ocasiones más frecuentes en que las imágenes exudaban de forma milagrosa (Christian 2009a), como en las afueras de la localidad de Cabra del Santo Cristo (Jaén) en 1698 (Gila Medina 2002: 58-59)

A comienzos del siglo xx se publicaban en Castilla la Nueva dos tipos de noticias de prensa sobre las peticiones de lluvia: las que se limitaban a mencionar que se estaban celebrando, y las que festejaban su éxito. Las procesiones interrumpidas o seguidas de inmediato por la lluvia se citaban como prueba del poder de Dios o de la fuerza de la oración, o como demostración de que el santo cuya ayuda se había invocado brindaba una especial protección a la localidad correspondiendo a la confianza y el amor del pueblo. Si la procesión tenía éxito, solía celebrarse una solemne misa cantada en acción de gracias, seguida por una procesión festiva para de-

32 Ver casos de Castilla la Nueva en Viñas y Mey (1951, t. I: 253), que sitúa en 1575 el de una niña tullida de cinco años curada por la efigie de № Sra. de la Alcoba al pasar en una rogativa para pedir lluvia en El Casar de Talavera; y la caída de una sustancia lechosa en 1664 durante una procesión de acción de gracias por la lluvia en Auñón (Guadalajara) (Castellote 2010: 81-82). 
volver la imagen al santuario y una homilía, que solía ser de tono emotivo. En casos de éxito espectacular podía realizarse una colecta y llevar predicadores de Madrid o de la sede diocesana para el sermón, además de contratar una orquesta para la misa y una banda municipal famosa para la procesión ${ }^{33}$.

Las procesiones eran generalmente actos cívicos solicitados a los ayuntamientos principalmente por los agricultores, a veces a través de cofradías. Eran sufragadas por los gobiernos municipales y encabezadas por el alcalde y los concejales. La corporación municipal solicitaba al clero de la localidad oraciones para impetrar lluvia, y los clérigos solían fijar el plan y el protocolo para las súplicas, no sin que se produjera de vez en cuando alguna tirantez (Cortés Peña 1995b) ${ }^{34}$.

Las informaciones de la prensa católica elogian en general al predicador e insisten en que las procesiones contaban con la asistencia de todo el mundo, incluidos pobres y ricos. Esta insistencia tiene una historia de hondas raíces, pues en la Edad Moderna se consideraba que tanto las procesiones anuales realizadas en función de algún voto, como las que estaban motivadas por una necesidad urgente, requerían la participación plena de la población para ser eficaces. Esta participación se conseguía de diversas maneras, imponiendo multas a las familias que no enviaban a algún miembro u ofreciendo incentivos consistentes en indulgencias o comida ${ }^{35}$. En el siglo xx, sin embargo, la situación varía sustancialmente. En un medio ideológico que había experimentado cambios radicales, las informaciones de la prensa católica que hablaban de un tiempo atmosférico sensible a las oraciones servían para que los lectores creyentes reafirmaran la existencia y el poder de Dios.

En cambio, según la izquierda, las oraciones para pedir lluvia (o para que cesara, o para evitar el granizo) formaban parte de una estrategia a largo plazo de los miembros del clero, a quienes se consideraba manipuladores cínicos que utilizaban los fenómenos meteorológicos para controlar la sociedad, estrategia cuya desarticulación podría ser un medio para incremen-

33 Guadamur en El Castellano [Toledo] 29 de mayo de 1909, 3 (un obispo auxiliar y un antiguo ministro de la Guerra en la ceremonia de acción de gracias), y Urda en $E l$ Castellano, 31 de mayo de 1921, 3.

34 Está por escribir un estudio comparativo de los distintos rituales de oraciones y rogativas para pedir lluvia que tenga en cuenta las zonas decisivas y la diversidad geográfica.

35 Christian (1991: 81-82, 146-7), para el texto de Ajofrín. Caridades en ibid. (57-58, 78-82), y en Faci (1979, 1: 129-30), Torrente (Fraga) 1703 (ibid., 2: 486) (c. 1737), Belsué (№ Sra. de Linares) (ibid., 2:119), Fañanás (№ Sra. de Bureta) 1737. 
tar la conciencia de campesinos y jornaleros. Como escribía el corresponsal de Gallur para el semanario zaragozano de la UGT, "el pedrisco, las cosechas, la sequía, etc., han sido manejados por ellos en sus discursos bélicos para atemorizar al pobre campesino de que Dios le castigaba por haberse desviado de la senda del bien. Y si sucedía lo contrario, ¡ah! entonces, Dios sabía premiar con largueza a sus sumisos corderos" (Miramón 1932). Los autores de esta literatura republicana solían ser profesionales liberales cuyo conocimiento de la agricultura era, en el mejor de los casos, teórico. En sus ataques contra el clero rural acababan ridiculizando también al campesinado.

Además de su valor como procesión sin lluvia, de su procedimiento innovador que no tuvo el resultado esperado, y de una aparición no confirmada, la visión de Toribia fue insólita para su época por ser ella quien era, por lo que se le apareció, y por el trato mantenido entre ambos.

\section{VISIONES}

La visión de Toribia fue diferente de las de los demás videntes que conocemos en torno a 1931, por lo general niños o adolescentes que parecían influidos por las visiones modernas de Lourdes y Fátima, y más tarde de Ezkioga. Las noticias sobre estas visiones famosas eran accesibles por diversos medios — revistas piadosas, grutas locales, relatos de peregrinos, estampas, postales, espectáculos de linterna mágica o películas-. En cambio, la historia de Toribia fue un regreso a modelos más antiguos: apariciones de santos y de la Virgen a laicos anónimos, y a menudo insignificantes, de medios rurales de la España y la Europa meridional de los siglos $\mathrm{XIV}, \mathrm{XV}$ y XVI, que reclamaban procesiones para solucionar problemas locales. La mayoría de esas visiones documentadas mediante testimonio notarial se produjeron en tiempos de epidemias. Una vez que los videntes habían convencido a las autoridades, se celebraba la procesión, la señal quedaba confirmada de algún modo y se establecía un nuevo vínculo entre la localidad y lo divino.

Esta clase de sucesos documentados, varios de los cuales provienen de Castilla la Nueva y en los que los videntes son hombres o niños, son representativos de un gran número de otros casos no documentados, muchos de los cuales perviven como leyendas y en los que las videntes son seglares adultas a las que la iglesia y las autoridades civiles de las edades Media y Moderna tomaban menos en serio (Christian 1990: 244-248; Caciola 2003; Elliott 2004). Ésta fue, quizá, una de las razones de que el caso de Toribia careciera de interés periodístico y no quedara documentado, pues se trataba de una mujer madura y casada. 
A comienzos del siglo XVI, la Inquisición puso fin a este sistema de contacto con lo divino persiguiendo, entre otros, a videntes laicos de pueblos situados entre 60 y 80 kilómetros al noroeste de Casas de Benítez ${ }^{36}$. Pero la mayoría de los casos documentados de la Baja Edad Media difieren del de Toribia en que los seres aparecidos eran claramente personajes no humanos: tenían un tamaño reducido, como el de las estatuas, o emitían una luz potente o poseían poderes especiales.

En algunos de ellos, sin embargo, se trataba de figuras masculinas con aspecto humano, y posteriormente se supuso que eran ángeles. Un caso similar al de Toribia (esta vez, la vidente fue una mujer mayor que se hallaba en su huerto, y la solución propuesta fue una procesión) ocurrió, según se creía, en Ayora, a 100 kilómetros al sureste de Casas de Benítez. Una anciana llamada Liñana llegó, al parecer, a su huerta situada junto a la calzada principal que iba hacia el norte y se encontró con un joven, quien le mandó decir a las autoridades del pueblo que celebraran una procesión anual a aquel lugar para poner fin a la peste. Al explicarle ella que no la creerían, el joven escribió un mensaje en la mano de la anciana. La historia, ocurrida supuestamente en enero de 1392, se conoce desde finales del siglo XVI. En la iglesia parroquial cuelga un cuadro del Ángel Custodio de Ayora pintado por Vicente López en 1802; y en el lugar de la visión hay una capilla dedicada al Ángel (Perales, sin fecha) ${ }^{37}$. (fig. 3).

Este encuentro no guardaba relación con una sequía, como tampoco la guardó otro similar, pero mejor documentado, ocurrido en Jafre (Girona) en 1460. En este último, un caminante indicó, también en tiempos de peste, que el agua de un manantial curaría a la gente ${ }^{38}$. Las sequías no parecen haber generado el mismo grado de angustia ni el mismo volumen de documentos que las pestes, en las que había una amenaza inminente de muer-

36 Christian (1990: 199-236): en 1514 (cuando un pastor vio a san Roque cerca de Santa María de los Llanos), 1516 (cuando el mismo pastor vio a Nuestra Señora de los Dolores cerca de El Toboso), y 1523 (cuando una joven casada de Quintanar de la Orden vio de noche a Nuestra Señora en el umbral de su casa).

${ }^{37}$ Ver también la página web del santuario: <www.valledeayora.net/tradicionpopular/ elangeldeayora/index.htm>, consultada el 22 de febrero de 2011.

${ }^{38}$ En Jafre (Girona), un joven caminante vestido de azul preguntó a un labrador cuántas cruces camineras había en el pueblo, y a continuación le dijo que debía haber más, le reveló las propiedades curativas de un manantial y, finalmente, como prueba de lo que había dicho, le comunicó la muerte inminente de un bebé. La muerte predicha fue confirmada por el doblar de la campana de la iglesia cuando el campesino marchaba a comunicar el mensaje al párroco. El santuario de la Mare de Deu de la Font Santa, edificado a raíz del hecho, existe todavía. El testimonio sobre las visiones fue tomado cuando se construyó el santuario, en 1461 (Christian 1990: 173-180). 
te. Pero como la gente buscaba con afán alguien que le prestara ayuda, no debería extrañarnos que algunas procesiones para impetrar lluvia tuvieran también su origen en visiones ${ }^{39}$.

La historia de una visión en Piera (Barcelona) es similar a la de Casas de Benítez (la vidente es una anciana; la visión, un caminante que pide comida; la circunstancia, una sequía; la solución, una procesión). El Sant Crist de Piera original, quemado en la Guerra Civil, era una impresionante imagen de un Cristo en agonía de finales del siglo XIV o principios del XV. En época de sequía, y sólo entonces, se sacaba en procesión de la iglesia parroquial, al menos desde 1691. Una fotografía capta el momento clave de una rogativa celebrada hacia 1905 en que la imagen sale de la iglesia en

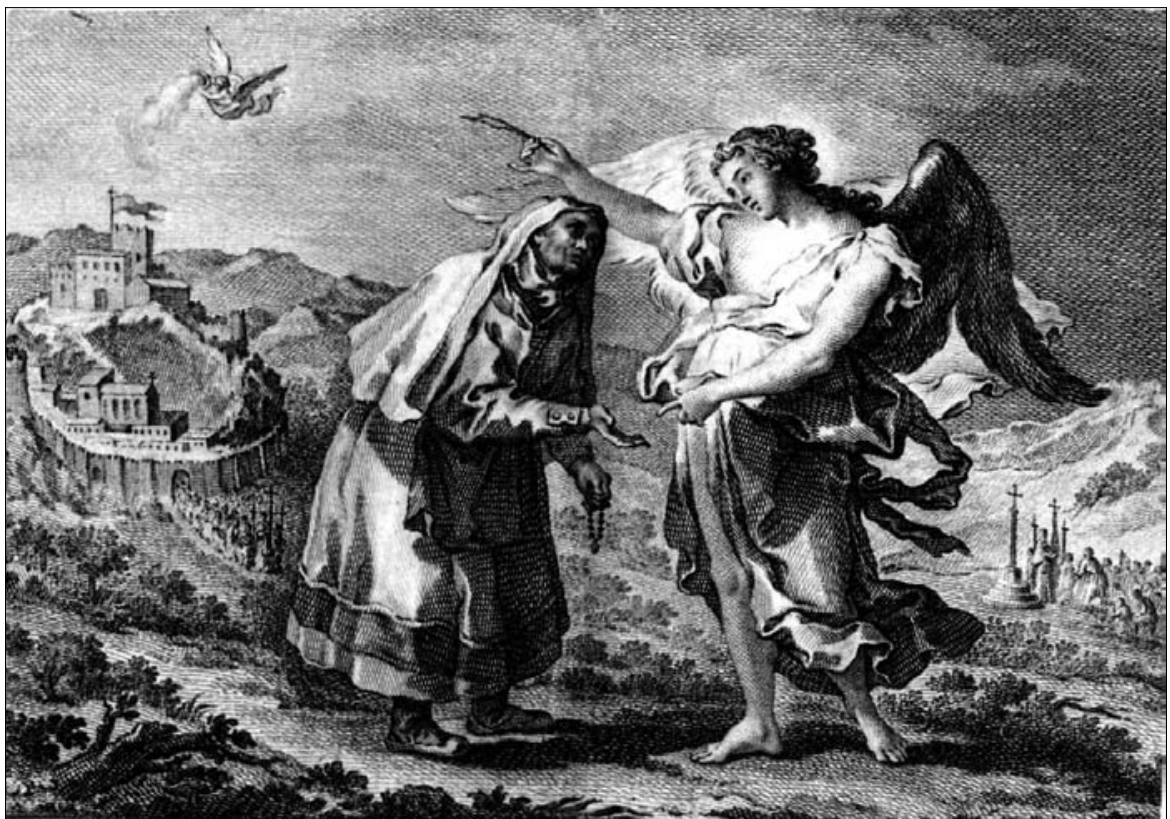

FIG. 3. El Ángel Tutelar de Ayora, grabado en M. Perales, Memorias de la aparición de un ángel en la Villa de Ayora (Murcia, Juan Vicente Teruel, principios del siglo XIX), basado en el cuadro de Vicente López Portaña.

39 A comienzos del siglo XVI, los habitantes de Ajofrín, cerca de Toledo, creían que una visión similar a la de Toribia se hallaba en el origen de su rogativa anual de largo recorrido. Una damisela se apareció a un pastor en los Montes de Toledo, le preguntó "qué era lo que se decía o trataba en el mundo y las necesidades que había", le dijo que fuera a Ajofrín y pidiera la celebración anual de una procesión para impetrar lluvia, y le proporcionó una prueba para que le pudieran creer (el cayado se le quedó pegado a la mano). Texto completo en español en Christian (1991: 280-283). 
presencia de un obispo y numerosos sacerdotes de los pueblos de los alrededores llegados con sus feligreses. (fig. 4).

Según el relato contado en Piera desde el siglo XVII, por lo menos ${ }^{40}$, durante una sequía que duraba ya dos años, un joven vestido como un pobre peregrino llamó a la puerta de Maria Lleopart, una viuda virtuosa que vivía en una aldea a doce kilómetros del centro. El joven pidió una limosna o pan, pero ella le dijo que no tenía ni una corteza. El peregrino le comentó que el Señor procuraría lluvia si celebraban una procesión solemne con cierta imagen de Cristo abandonada en un rincón del hospicio de San Francisco, en las afueras de Piera. Como prueba, el peregrino le dijo que mirara en su despensa. La mujer sabía que no había nada en ella, pero el joven insistió. Maria Lleopart entró en casa y descubrió que, realmente, había pan, pero el peregrino había desaparecido. María lo contó al cura y a las autoridades municipales de Piera, que localizaron la imagen y la sacaron en procesión el 28 de abril. Este grabado del siglo XVIII muestra al Cristo en procesión, y a la derecha, en primer término, a un peregrino con alas señalando el Cristo a la campesina. (figs. 5 y 6 ).

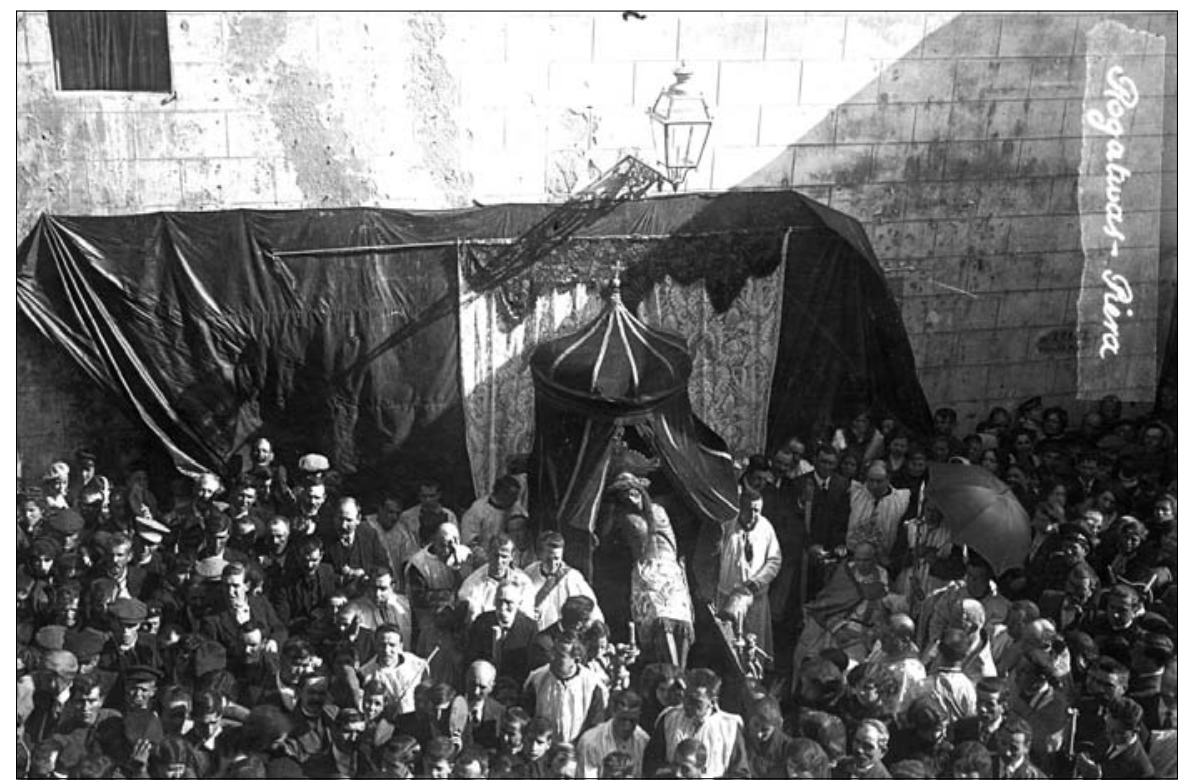

FIG. 4. El Sant Crist de Piera sale en rogativa, c1905-1910. Foto: Sagarra, colección del autor.

${ }^{40}$ El relato recogido aquí es de Crospis (1764) y del Compendio (1833: 1-5), que se basan en narraciones orales y sitúan la historia quinientos años antes. 


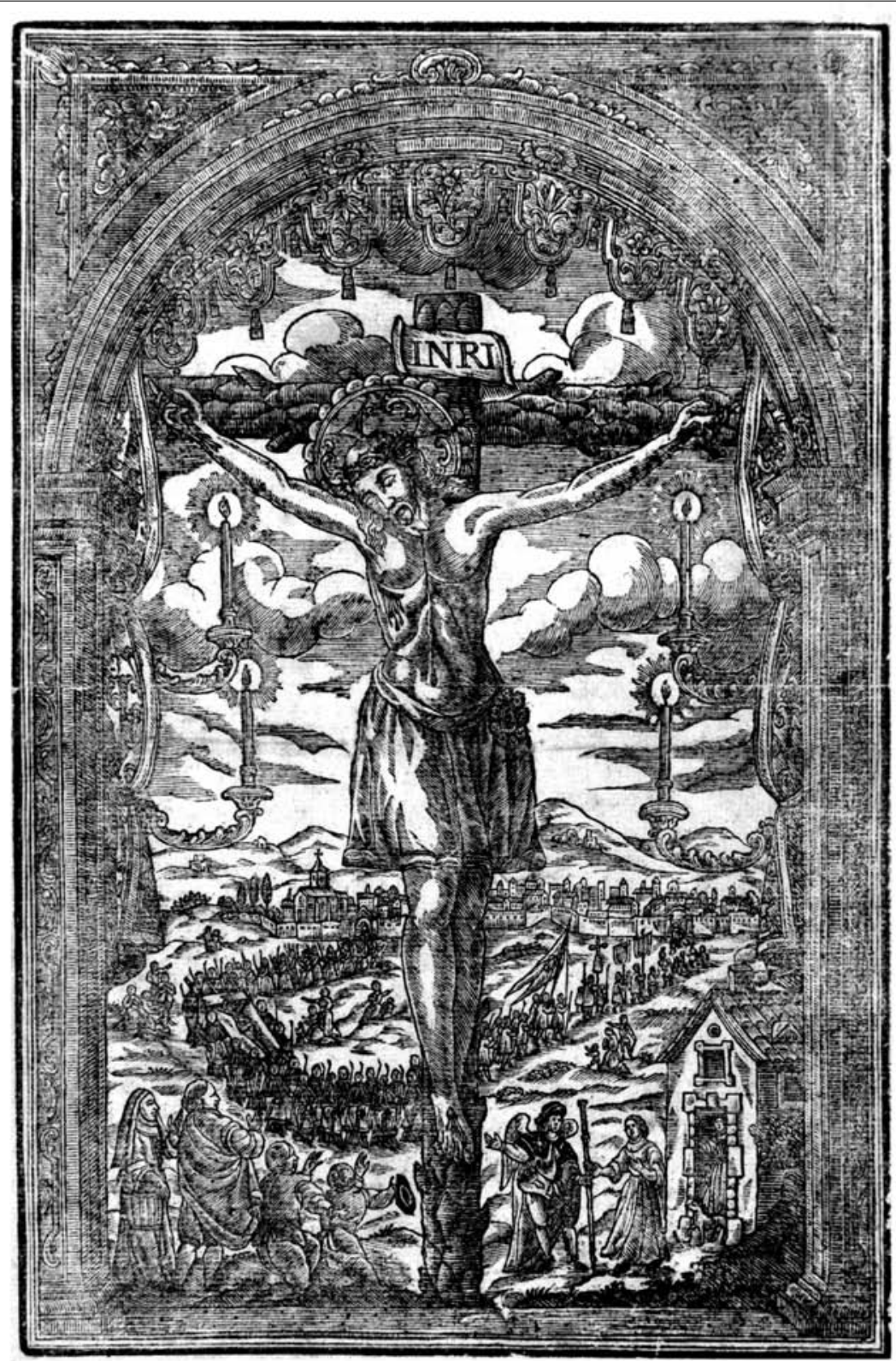

LA PRODIGIOSA IMATGE DEL SANT CHRISTO DE HERRA.

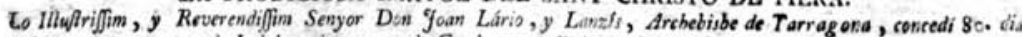
de Irdulgencia, fer cads Credo, que ürăs devint de ala S. Imatee.

FIG. 5. El Sant Crist de Piera. Con permiso, Biblioteca de Catalunya. 


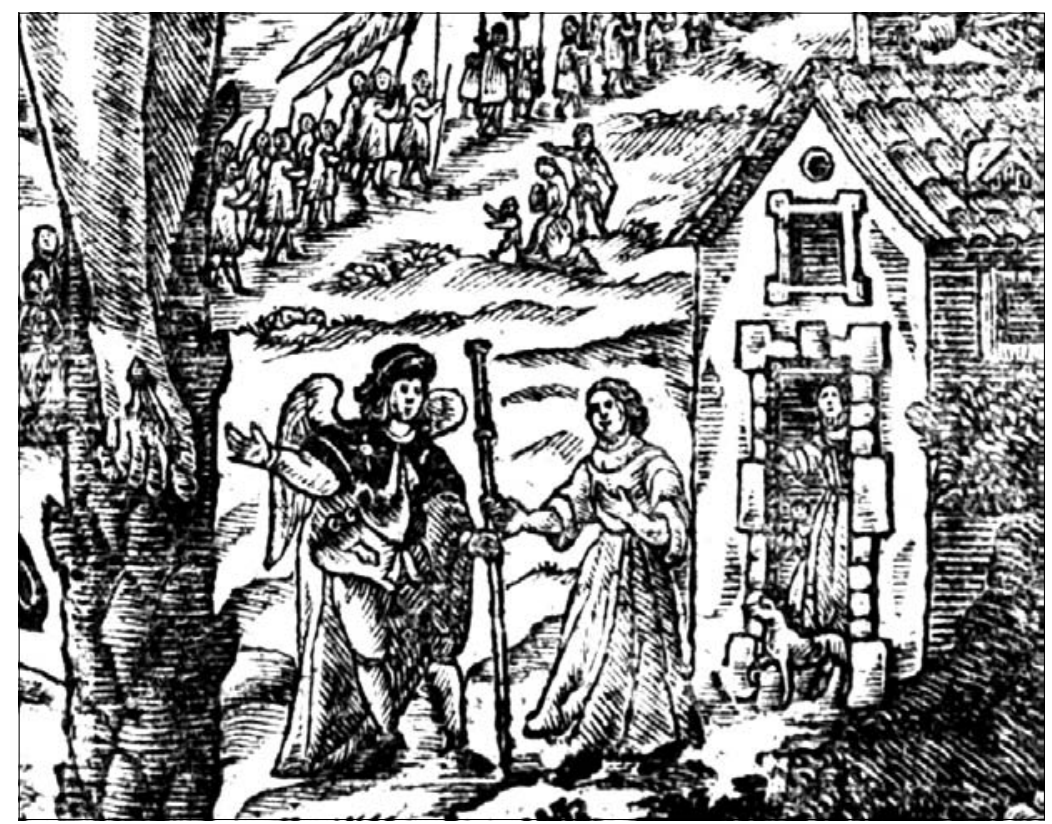

FIG. 6. El Sant Crist de Piera, detalle, la aparición.

Con permiso, Biblioteca de Catalunya.

En casi todos estos relatos de apariciones, el encuentro se produce fuera de la localidad, en un espacio destinado a huertas, ovejas y caminantes, y el mensaje hace salir al campo a la población con sus imágenes. Fuera del pueblo, sus habitantes encarnan su organización civil sin la protección de edificios, y son vulnerables a los elementos, como un cangrejo ermitaño fuera de su caparazón. En esos grabados y pinturas, su sociedad se les muestra visiblemente en ordenada jerarquía, lista para ser representada. (fig. 7).

PEREGRINOS Y MENDICANTES

Es evidente que esta clase de historias influyeron en Francisco Martínez, un pastor trashumante de 34 años de la localidad de Taravilla, en la diócesis de Cuenca, en su intento de convertirse en guardián de un santuario y recaudador de limosnas. Según su confesión a la Inquisición, prestada en 1728, un peregrino le pidió agua, y "con este motibo me pareció fomentar que le auía rebelado algunas cosas y entre ellas que auía de llober de la misma suerte que el santo christo que tenía sudaba sangre" ${ }^{41}$. Antes de

${ }^{41}$ El texto original en español se halla en Christian (1989: 103-104); en la transcripción ofrecida aquí me he tomado la libertad de convertir el discurso indirecto en directo. 


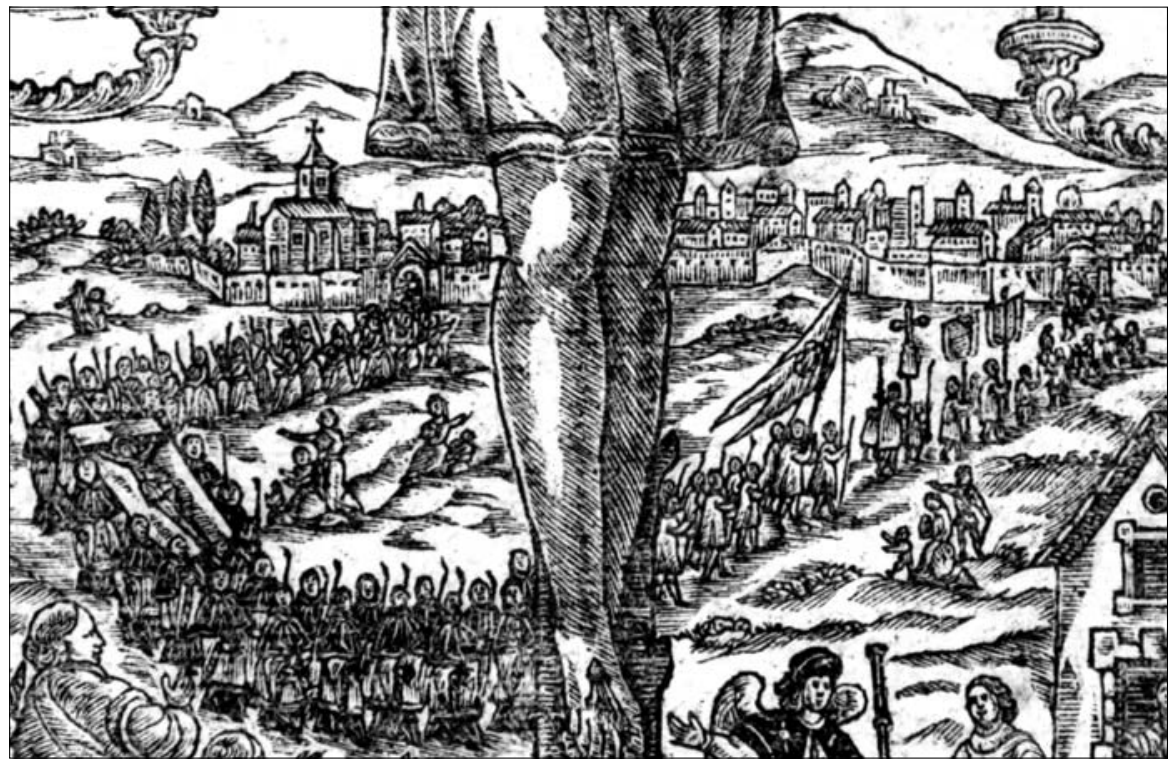

FIG. 7. El Sant Crist de Piera, detalle, la procesión. Con permiso, Biblioteca de Catalunya.

que se llamara a la Inquisición, Francisco había estado contando a todo el mundo la historia inventada, incluso ante un notario público, que la puso por escrito.

Hallándome guardando una dehesa de la Villa de san Esteban en Andalucía por el mes de noviembre del año próximo pasado en la que auía de pastar una manada de Don Antonio Velázquez vecino y rexidor perpetuo de [Molina de Aragón], una tarde de dicho mes, estando sentado en la puerta de un cortijo que estaba cerca de ella al concluir la devoción que tenía de rezar el rosario y tres credos, oí una voz. Y buelta la cabeza a ella vi un peregrino que me pidió le diese por Dios un poco de agua. Y le respondí que así el Señor la imbiase para los campos como la mantenía en las fuentes para los pecadores. Con lo que entré en el cortijo y le saqué una cantarilla de barro a modo de jarra llena de agua. Y el vebió hasta un quartillo. Y buelto a salir le pregunté si abía llobido por las partes de donde benía. Y me dixo que en partes abía llobido y en partes no, y que en aquella tierra llobería por Santa Lucía.

Según afirmó Martínez, el peregrino le reveló a continuación que, donde quiera que se hallase el día de la Ascensión, el crucifijo portado por él sangraría y se produciría un milagro, y luego se marchó. Cuando Martínez entró en casa descubrió que la cantarilla de la que había bebido el peregrino había vuelto a llenarse milagrosamente. 
Preguntado por el aspecto del peregrino, Martínez describió algo semejante a un cuadro o una estatua, en realidad algo parecido, en versión peregrino, al cuadro del ángel de Ayora obra de Vicente López: “...como de diez y ocho años, poco mas o menos, muy rubio de cabellos, zejas, y barba con túnica entre blanca y morada zeñida por la cintura sin saber con qué, los ojos negros y inclinados al cielo, las mexillas blancas y encarnadas, descalzo de pie y pierna, con un bordón en la mano al remate una bola el que estaba usado". Según su descripción, la capa de peregrino tenía también una cruz de Caravaca.

Desde las visiones medievales hasta los relatos de Ayora y Piera, y las fabulaciones de Francisco Martínez reconocemos una especie de linaje. La naturalidad con que los habitantes de Casas de Benítez, Pozoamargo y los pueblos de los alrededores consideraron y sopesaron la visión de Toribia, y actuaron en función de la misma, y la actitud exenta de juicios morales de los suyos cuando informan ahora sobre ella o la analizan nos llevan a suponer que hubo otros episodios del mismo tipo, en un diálogo entre relato y suceso de larga duración.

En efecto, en una localidad de la misma región se produjo una visión similar cuatro años después de la de Toribia y uno antes de la Guerra Civil. El semanario ilustrado madrileño Estampa informó sobre un misterioso visitante que había traído noticias de lluvia. El encuentro se produjo en las afueras del pueblo de Burguillos, a 12 kilómetros de Toledo y 165 al noroeste de Casas de Benítez. También en este caso se trató de un suceso muy local con repercusiones mínimas; hasta donde sabemos la familia del vidente y yo mismo, no fue mencionado por ninguna otra publicación. Estampa rellenó su relato, un tanto anticlimático, con fotografías de los videntes de Ezkioga, Beauraing, Fátima y Lourdes (Sánchez Ocaña 1935). (fig. 8).

El lunes de Semana Santa, Fausto del Castillo, un muchacho de dieciséis años, se hallaba ayudando a unos jóvenes que estaban cavando un pozo y lo enviaron por agua a una fuente. Allí, dijo el muchacho, había encontrado a un anciano peregrino erguido y en silencio, con larga barba gris y pelo blanco, vestido con un hábito marrón y calzado con sandalias. El peregrino hizo dos preguntas súbitas y una observación: "¿Para quién es el agua que coges?" "¿Tiene agua ya el pozo? Pronto la tendrá”, y se marchó siguiendo el curso del manantial.

Al día siguiente, el peregrino volvía a estar junto a la fuente, esta vez descalzo y vestido con un hábito de color púrpura. Preguntó de nuevo por el pozo, repitió que daría agua y pidió de beber. Bebió tres veces de un vaso de hojalata y dijo a Fausto que fuera a misa a la mañana siguiente y la oyera de rodillas. En esta ocasión, Fausto se lo contó a su familia (sus padres tenían una tienda de ultramarinos) y a sus amigos, repitiendo una y 


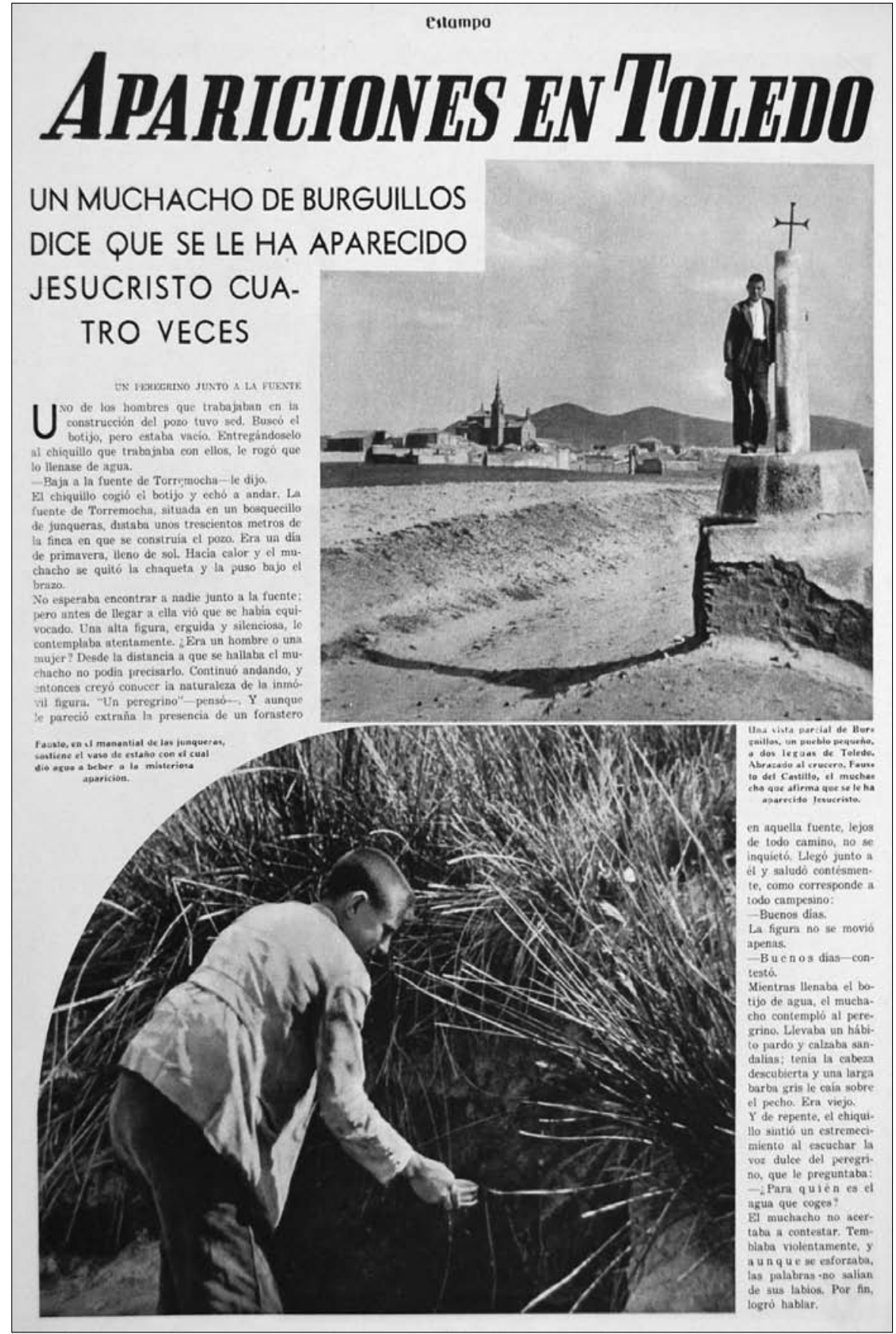

FIG. 8. Estampa (Madrid) 25 Mayo 1935 p. [3]. 
otra vez: “¡Es Jesucristo! ¡Es Jesucristo!” La mitad del pueblo le creyó, mientras que la otra mitad se mostró escéptica.

El miércoles oyó misa tal como se le había ordenado y fue a la fuente con su hermano menor y un amigo que se había burlado de las visiones. No había nadie y llenaron la jarra de agua; pero, a la vuelta, en un momento en que su amigo se reía, Fausto sintió un golpe en la mejilla y cayó inconsciente; la jarra se rompió. Los obreros lo reanimaron, y algo más adelante se encontró con el peregrino, quien le dijo que la bofetada era por no haber ido solo. En la mejilla de Fausto había marcas de dedos, y la gente acudió de los pueblos de alrededor a escuchar su relato, pero él se mostró apesadumbrado y taciturno.

Fausto se quedó en casa los dos días siguientes, pero cuando salió a una hora temprana del sábado a dar de comer al caballo de la familia, el peregrino estaba en la carretera y el muchacho le rogó que le hiciera saber qué deseaba: "Yo te diré lo que deseo, no me tengas miedo". Pero aquélla resultó ser la última visión de Fausto, y cuando el periodista y el fotógrafo llegaron de Madrid y hablaron con su familia, Fausto se mostró reservado.

En junio de 2010 fui a Burguillos con una amiga antropóloga, una amiga de ella residente en Toledo, y una amiga de ésta que vive en Burguillos. Allí hablamos con Elena del Castillo, sobrina de Fausto, que contó la historia según la sabía antes de que yo le enseñara el artículo de la revista, del que tenía noticia pero que no había visto. Su madre, hermana de Fausto, había fallecido cuando Elena tenía 14 años. Su padre y los dos hermanos de éste eran quienes habían estado excavando el pozo en 1935 y habían enviado a Fausto por agua ${ }^{42}$. El padre de Elena contó a ésta que Fausto había vuelto de la fuente asustado y diciendo que había tenido una aparición de un fraile, y que la jarra del agua se había roto. Uno de los tíos de Elena había ido a comprobarlo, pero no vio a nadie.

Elena tenía una foto de Fausto con uniforme militar republicano que se publicó en el libro de fotografías históricas de la localidad (Díaz Hernández 1994: 135). En Burguillos habían sido quemadas todas las imágenes de la iglesia, lo mismo que en Casas de Benítez. Cuando las tropas de Franco tomaron Toledo, dos tíos de Elena, los dos que habían estado cavando el pozo con su padre, fueron encarcelados y, más tarde, sacados y fusilados. Fausto marchó exiliado a Francia y no volvió de visita hasta la década de 1970. Jamás se atrevieron a preguntarle por sus visiones, y él no las mencionó nunca a su mujer y sus hijos, quienes leyeron el artículo en una biblioteca de Toledo y fueron a ver la fuente, pero no comentaron el asunto con él. Fausto se llevó a la tumba cualquier otra cosa que tuviera que contar.

\footnotetext{
${ }^{42}$ Elena los había imaginado segando, y no cavando un pozo.
} 
¿Cómo se extienden estas tipologías a lo largo de un periodo de siglos? ¿Qué es lo que vincula estos lugares y tiempos dispares en un tema de carácter minoritario? Hasta donde yo sé, el modelo tipológico no está identificado ni ha sido recogido en la voluminosa literatura piadosa sobre santos, santuarios y milagros. ¿Se debe esta falta de atención a que esa clase de visiones eran demasiado raras o muy distantes una de otra en el tiempo y el espacio, o a que las referentes a la lluvia no solían ser registradas, a diferencia de las relacionadas con la peste? La gente ve y oye cosas extrañas continuamente; pero, ¿cómo es que ven y oyen otras tan similares? -lo bastante similares como para ser reconocibles, y con suficientes toques individuales (las habas, la alacena repleta de pan, la cantarilla llena, la jarra de agua rota, las marcas de una bofetada en la cara) como para conferirles carácter distintivo.

Ante todo, el trasfondo de forasteros caminantes es común a todo el periodo que va de la Edad Media a la Guerra Civil española. Entre otros caminantes, forasteros en diversos grados (pastores trashumantes, segadores, mendigos, gitanos, buhoneros, caldereros y, más tarde también, viajantes de comercio, feriantes, fotógrafos ambulantes, compañías de circo y teatro), los peregrinos aislados que podían cruzar Castilla la Nueva camino de Guadalupe o Santiago habrían sido los menos conocidos de todos. En este sentido eran los forasteros más extraños.

Pero la mayoría de los españoles, al menos en los quinientos últimos años, habrían sabido de inmediato qué eran en función de su atuendo, idéntico al del popular san Roque. En 1590, la Corona intentó acabar con el vagabundeo prohibiendo el uso de "ábitos de romeros y peregrinos" a los españoles que iban en peregrinación, pero permitiéndoselo, no obstante, a los extranjeros. Estos hábitos incluían prendas como “... esclavinas y sacos de sayal, y otros paños de diuersas colores, y sombreros grandes con insignias y bordones..." (Premática 1590: f2 verso). Bien entrado el siglo xx (y con la reactivación del peregrinaje a Santiago, generalizada nuevamente en la actualidad), hubo peregrinos clásicos barbudos como éste, fotografiado en Roncesvalles hacia $1900^{43}$. (fig. 9). La gente los recordaba todavía cuando

${ }_{43}$ Diario Español (Tarragona), 3 de agosto de 1947, 3: "Un peregrino en Tarragona. Ha estado en nuestra Redacción el penitente de San Roque, Jerónimo Barrachina, el cual se propone visitar todos los santuarios de España. Barrachina es natural de Alcoy y con la peregrinación que está llevando a cabo da cumplimiento a una promesa. También se propone una vez cumplida su promesa ir andando a Roma a postrarse ante Su Santidad". Yugo (Almería) 8 de agosto de 1947, 4: "Ayer nos visitó el peregrino Vicente Maestre, que va recorriendo España, habiendo estado ya en las principales provincias llevando un haber de 10.773 kilómetros. El citado peregrino es natural de Petrer, provincia de Alicante, a cuya ciudad se dirige ahora. Comenzó a recorrer nuestra nación en el año 1945, deteniéndose principalmente en pueblos y aldeas donde da testimonio de su misión 


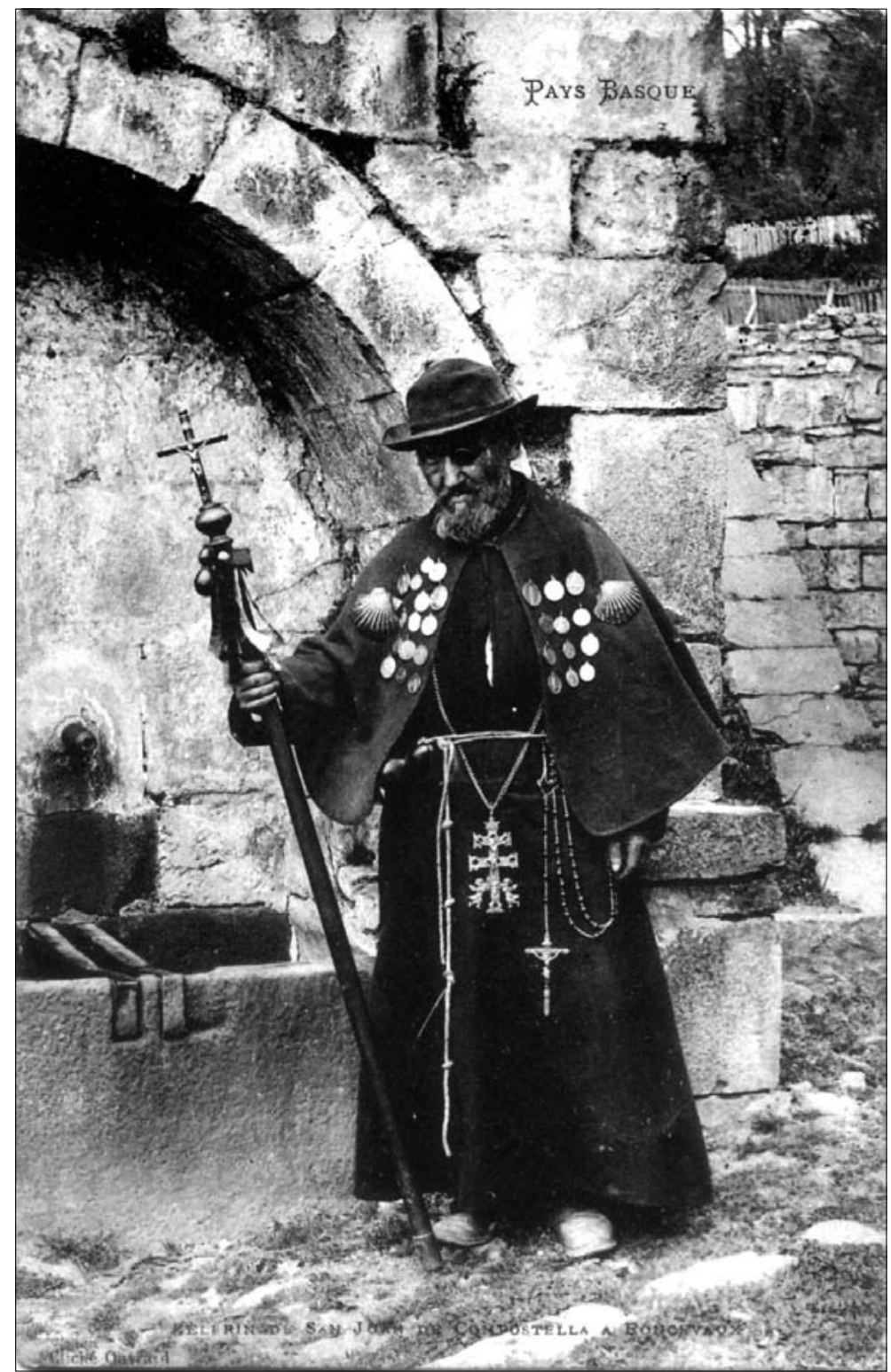

FIG. 9. "Pays Basque: Pèlerin de Saint Juan [sic] de Compostella à Roncevaux". Foto Ouvrard, enviado desde Biarritz en 1904, colección del autor.

peregrinante”. El antropólogo catalán Joan Prat (2010) recorrió el Camino de Santiago en el verano de 2010, y entre los personajes con quienes se encontró había un peregrino perpetuo que vivía de limosnas; había hecho la ruta seis veces y confesó a Prat que estaba completamente harto de ella. 
realicé una gira por diversos santuarios en la década de 1960. Se tenía cierta idea de que podían ser santos, como morabitos o frailes mendicantes con hábitos similares, y existen cultos locales cuyo fundamento son peregrinos reales, mujeres u hombres, y que están dedicados a los propios peregrinos, considerados santos ${ }^{44}$, o a reliquias o imágenes que dejaron al marchar ${ }^{45}$. Cuando hice el Camino de Santiago, en 1965, fui tratado con un respeto y una curiosidad considerables, incluso sin hábito ni barba ${ }^{46}$.

La hondura de la penetración de estas ideas entre los españoles puede deducirse del catecismo de Antonio María Claret, con numerosas ediciones desde 1848 hasta la Guerra Civil de 1936. Entre las Siete Obras de Misericordia se enumeran dar de comer al hambriento, dar de beber al sediento y dar posada al peregrino. El catecismo de Claret estaba ilustrado con xilografías y comentarios que ejemplificaban la clase de fundamento bíblico, imperante en el discurso clerical del pasado, en que se basaba la tipología que hemos estado viendo. (fig. 10).

El hombre que pide de beber (como el de Burguillos) tiene una aureola, y el comentario explica que es Cristo ante la samaritana junto al pozo de Sicar; la mujer no sabe quién es y se lo niega (Juan, 4:10). (fig. 11). El comentario advierte: "Piensa que cualquier pobre representa a Jesucristo; no serías tú el primero a quien el mismo Jesucristo, bajo la apariencia de un mendigo, pidiese una limosna" (Claret 1852: 443). En España, esta fusión entre mendigos y santos se representaba de diversas maneras. En Caldes de Montbui, una cofradía hacía que en su procesión anual marcharan doce

\footnotetext{
${ }^{44}$ Como en el caso del peregrino/ermitaño húngaro san Vintila (m. 890), en Punxin, Galicia. La capilla de Loreto, en La Almunia de Doña Godina [Zaragoza], fue fundada, según se cuenta, en el siglo Xvir por un peregrino catalán, Jaime de la Carrera, que llevó la imagen y se quedó como ermitaño (Pérez 1949, Libro V: 288). En La Época (Madrid), 20 de julio de 1888, 3, leemos lo siguiente: "Dice La Verdad, de Tortosa, que se ha convertido en verdadera romería el camino que conduce a la cueva donde se alberga una peregrina de conducta verdaderamente excepcional. Las infinitas personas que la visitan, en general mujeres de todas las condiciones, cuentan de la peregrina cosas estupendas. Según las relaciones que se hacen, su vida es tan austera y penitente que se atormenta el cuerpo con fuertes cilicios, duerme a la intemperie y sólo se alimenta de patatas cocidas con agua sola. Las limosnas que recibe, después de sufragar sus pobres atenciones, las reparte a los pobres, no guardando, cerrada la noche, ni un céntimo para el otro día. A más confiesa y comulga todos los días".

${ }^{45}$ Reliquias dejadas por un peregrino enfermo que falleció en Escalonilla a comienzos del siglo XVI (Faci 1979, t. 1: 382-3); imágenes del crucificado y de Ntra. Sra. de los Dolores de Alcañiz, dejadas por el peregrino Juan de León a comienzos de la década de 1570 (ibid., 1: 72-75).

${ }^{46}$ Sobre la larga duración del potencial de sacralidad del peregrino, ver Spaccarelli (1999, 2006).
} 


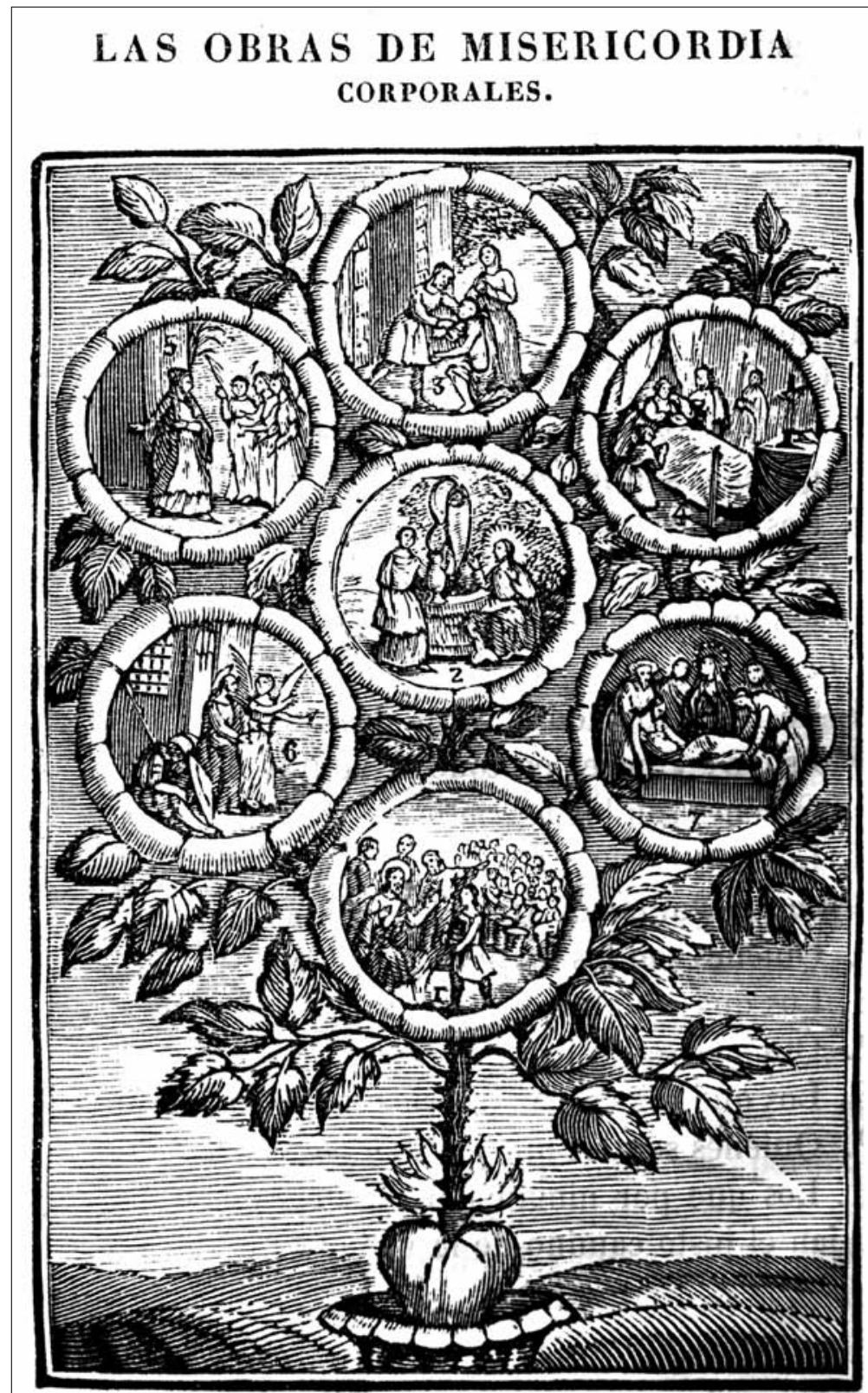

Con la misma medida con que midièreis, se os volverá á medir. (Luc. vı, 38).

FIG. 10. Las obras de misericordia corporales. Antonio María Claret, Catecismo de Doctrina Cristiana, Barcelona, Librería Religiosa, 1852, p. 440. 


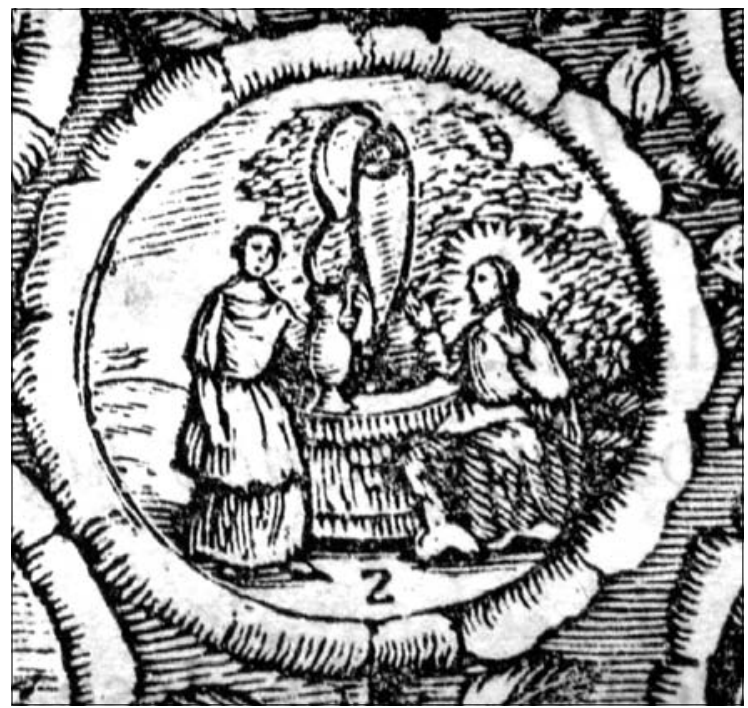

FIG. 11. Dar de beber al sediento. Claret, Catecismo, Las obras de misericordia corporales, detalle.

mendigos en representación de los doce apóstoles, hasta que la costumbre fue prohibida en 1771 por irreverente y profana (Kamen 1993: 181). Pero, a largo del siglo xx, el día de Jueves Santo, sacerdotes y obispos lavaban los pies de mendigos que representaban a los doce apóstoles, como lo hacía Alfonso XIII en una grandiosa ceremonia anual. En 1920 una cronista reflexionaba sobre la ceremonia real en $\mathrm{ABC}$ : “... al ver todas las grandezas de la tierra encarnadas en nuestros Monarcas, de rodillas ante los pobres, que representan a Jesucristo... una voz interna nos dice que España no sucumbirá, como otras naciones, bajo el dominio de los que quieren gobernar sin Dios" ${ }^{47}$. Y la idea de que los peregrinos o mendigos que iban de puerta en puerta pidiendo limosna o comida podían ser Cristo o un santo varón era expresada cada año en toda España en las peticiones navideñas de los niños conocidas como "La oración del Peregrino" (Pedrosa 1999).

\footnotetext{
${ }^{47}$ Safford (1920), después de dar una descripción de Alfonso XIII en el acto de lavar y besar los pies de doce pobres en presencia de grandes damas y esposas de embajadores. El reportaje se fija sobre todo en los modelos que llevaban las asistentes. La última ceremonia real se celebró el 2 de abril de 1931 ( $A B C, 3$ de abril, 5, 19-22). En Cuenca, en 1928, el obispo lavó los pies de doce ancianos observado por un público numeroso del que formaba parte el ayuntamiento de la ciudad (El Día de Cuenca, 6 de abril de 1928, 1). Gaya Nuño (1962: 160-162) relata la ceremonia del Lavatorio en la catedral de Jaén en 1953 y su posterior conversación con los mendigos, a quienes se abonaron 2 pesetas por cabeza.
} 
Los tres peregrinos que piden posada tienen alas, y merece la pena citar el comentario por extenso (Claret 1852: 444-445) ${ }^{48}$ : (fig. 12).

La quinta [obra de misericordia corporal] es: dar posada al peregrino. El n. $\stackrel{5}{5}$ representa al patriarca Abrahán que da posada a unos peregrinos que él pensaba ser hombres y en realidad eran Ángeles del Señor; y fue tanto lo que Dios apreció a Abrahán esta obra de misericordia, que por ella le prometió nada menos que hacerle padre de una numerosa descendencia y prodigarle abundancia de bienes espirituales y temporales. ¡Así premia Dios las obras de caridad a él y á los Angeles tan gratas! También los habitantes del castillo de Emaús juzgaron que era un hombre, un peregrino a quien daban posada, y en realidad era el mismo Jesucristo resucitado de tres días [Lucas 24:13-17]; así como aconteció a San Gregorio, que creyendo hospedar unos pobres peregrinos, se halló que eran Ángeles. ¡Felices, sí, los que en tales obras de caridad se emplean!, porque Dios les dará también eterna posada en su palacio celestial.

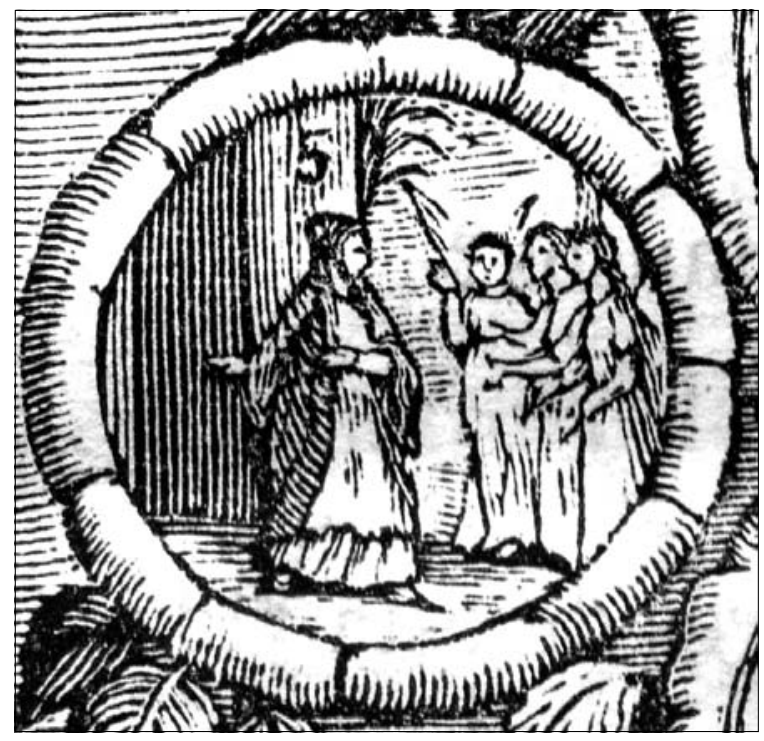

FIG. 12. Dar posada el peregrino. Claret, Catecismo, Las obras de misericordia corporales, detalle.

${ }^{48}$ En numerosas obras españolas de la Edad Moderna, por ejemplo en Diego de Estella (1524-1578), Tratado de la Vanidad del Mundo (Toledo 1562), Alfonso de Cabrera (15491598), Sermones, José Ortiz Cantero, Directorio Catequístico (1766, 253), etc., encontramos el modelo de Abraham — que acoge de manera ejemplar a los tres caminantes, a quienes ofrece agua para que puedan lavarse los pies, pan, leche y carne (Génesis 18:1 19) - como dechado de caridad y hospitalidad. 
Ni en los pasajes bíblicos ni en los relatos de la Leyenda Áurea sobre san Gregorio a los que se refiere Claret aparecen peregrinos. En España, esta fusión entre caminantes y peregrinos se debe, quizá, al número de peregrinos itinerantes. Y en tiempos de Claret resultó afectada, sin duda, por la fuerza misma de las historias de ángeles peregrinos examinadas aquí.

En Castilla la Nueva hubo durante la Edad Moderna otro tópico, desarrollado al parecer en el siglo XVII, que habla de peregrinos (a quienes luego se consideró ángeles) que dejaban pinturas o dibujos de crucifijos al carbón en los muros donde se habían alojado, y que, a su vez, fueron el fundamento de la creación de santuarios ${ }^{49}$. En otros lugares de España, el tópico —aplicable a algunos de los crucifijos más venerados- decía que en algún momento del pasado lejano habían llegado dos peregrinos, se habían ofrecido a realizar una imagen y, tras retirarse durante tres días a una habitación cerrada, habían desaparecido, dejando en ella la nueva efigie ${ }^{50}$. En México, donde los relatos datan del mismo periodo, los visitantes que llevaban o realizaban imágenes eran indios angélicos ${ }^{51}$. Estos relatos otorgan

${ }^{49}$ Villalba del Rey (Cuenca), s. XviI; San Carlos del Valle, c. 1640; y Cristo de Tembleque, 1689 (Christian 1991: 236, 238, 338-39). Esta tipología está ausente de las historias de santuarios documentadas en las Relaciones Topográficas de 1575-1580 para Castilla la Nueva.

${ }^{50}$ Para Aragón, ver en Faci (1979), las descripciones del Cristo de Calatorao; de un crucifijo roto recompuesto por un misterioso peregrino en Gelsa; del Santo Crucifijo de los Milagros en la catedral de Barbastro, realizado por dos peregrinos; del crucifijo de la iglesia colegial de Boltaña, hecho por dos peregrinos forasteros; de un crucifijo hecho por un solo peregrino en Alcolea; y en Alcorisa, de una imagen de San Sebastián, hecha por un peregrino durante la peste. Para otros lugares: Ntra. Sra. de los Desamparados (Valencia), imagen realizada por tres jóvenes (Villafañe 1740: 192-3); Ntra. Sra. del Coro (Lleida, clarisas), realizada por forasteros (Sánchez Pérez 1943: 141-2); Ntra. Sra. de las Nieves, Hondón (Alicante), en la que dos o tres peregrinos trabajaron durante tres días (ibid.: 290); Ntra. Sra. de las Maravillas, en Pamplona: el forastero se marchó para hacerse monje, 16 de julio de 1655 (ibid.: 250-1); Ntra. Sra. de la Luz, Lucena (Córdoba), dos jóvenes la dejan y desaparecen (ibid:: 357-8); y Ntra. Sra. del Tránsito, Zamora: dos peregrinos de Santiago trabajan durante dos días, finales del siglo XvI (ibid.: 409410). Velasco (2000: 94, 97) describe la pauta.

${ }^{51}$ Para México, William Taylor me ha proporcionado generosamente los siguientes ejemplos tomados de historias de santuarios y compendios piadosos de los siglos XVII y XVIII: un joven misterioso ataviado de blanco trae una imagen y desaparece (Cristo de Totolapa y Señor de las Batallas [Tlacolula, Oaxaca]); dos hermosos jóvenes entregan la imagen al santuario (un crucifijo, Tecaxic, cerca de Toluca); cuatro desconocidos vestidos con atuendo penitencial llevan una imagen (Cristo de la Columna, parroquia de Santa Catalina Mártir, Ciudad de México); unos indios tallan una estatua y desaparecen sin haber cobrado por ello (Jesús Nazareno, Hospital de la Purísima Concepción, Ciudad de México); unos indios músicos angelicales asociados al descubrimiento de una imagen y, seguidamente, de un cuadro (Nuestra Señora de Tecaxic, cerca de Toluca). 
una alcurnia celeste a imágenes ya veneradas y fueron, al parecer, el equivalente en el siglo XVII de la concepción más antigua según la cual ciertas imágenes habían sido pintadas por Nicodemo o san Lucas.

El paradigma bíblico de Claret para dar de comer al hambriento es Cristo alimentando a la gente en la montaña donde pronunció las bienaventuranzas. Esta distribución de hogazas es en sí misma un modelo del reparto de comida de caridad llevada a cabo en santuarios españoles en función de algún voto, de la entregada durante algunas rogativas para impetrar lluvia (vimos incluso que, en una procesión, la multiplicación de esas hogazas fue un milagro adicional), y, desde luego, de las tortas de caridad distribuidas por Toribia cada año en la iglesia de Casas de Benítez. Desde esta perspectiva, el que diera de comer habas al Cristo forastero y tortas a sus conciudadanos el día de la resurrección de Cristo eran dos hechos cortados por el mismo patrón. (fig. 13).

\section{PRemio o CASTIGo}

Las historias de Casas de Benítez, Piera, Ayora y Burguillos parecen mostrar una tipología más profunda y universal, propia de los cuentos de hadas. Son como relatos de mendigos y mendigas que piden comida o limosna y resultan ser hadas que otorgan tres deseos como recompensa por la generosidad según modelos identificados por los folcloristas. Carmen

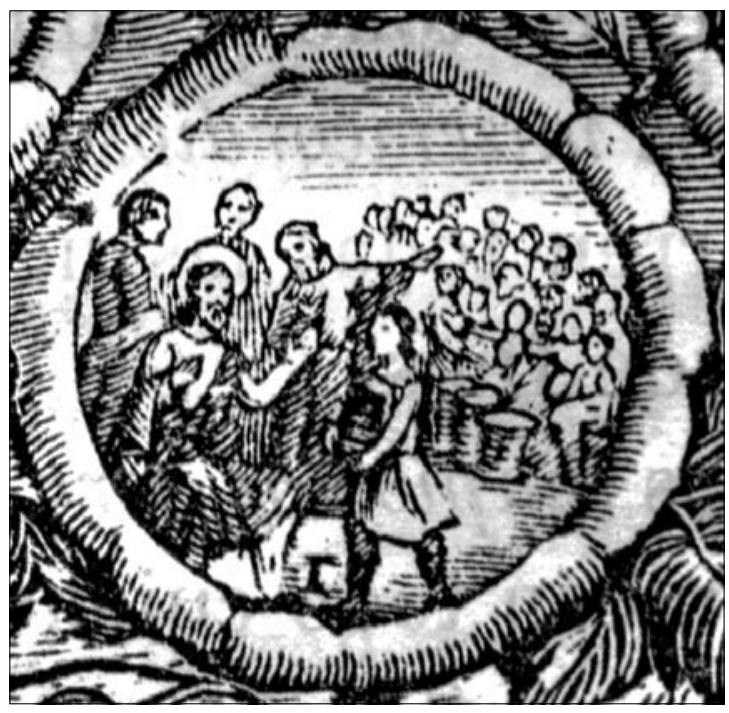

FIG. 13. Dar de comer al hambriento. Claret, Catecismo, Las obras de misericordia corporales, detalle. 
Blacker (1990: 63), que escribe sobre una tipología similar en Japón, resume así el modelo europeo: “... un forastero noble y santo vaga por el mundo disfrazado de mendigo recompensando con bendiciones el buen trato recibido y devolviendo un mal trato con maldiciones". Conocemos ejemplos de Hungría y España en los que Cristo se detiene para pedir a un vaquero un vaso de agua y le premia o castiga en función de su respuesta ${ }^{52}$.

En Casas de Benítez existe, de manera similar, la creencia de que las gitanas que piden de puerta en puerta pueden echar mal de ojo a los niños si son rechazadas. Un medio de protección usado en el pueblo, y del que informa Pascual Martínez (1996: 213-4), consistía en que los niños llevasen colgada del cuello una bolsita con un trozo de pan dentro; y hemos visto que, a finales de la década de 1930, algunos utilizaron el pan de Toribia ${ }^{53}$.

En los casos estudiados por nosotros, la noción de castigo infligido por el forastero misterioso se halla solamente implícita. Al fin y al cabo, Toribia le dio habas; Fausto en Burguillos y Francisco Martínez, el pastor, le dieron agua; y Maria Lleopart se mostró dispuesta a darle pan. Pero el visitante de Burguillos dejó sin sentido de un golpe a Fausto por haber llevado a un amigo incrédulo. Los modelos bíblicos contienen también ejemplos de rechazo. La samaritana del pozo no le quería dar agua a Cristo visitante (Juan, 5). Y dos de los ángeles acogidos por Abraham fueron luego a Sodoma, cuyos habitantes quisieron sodomizarlos, y la ciudad fue destruida tras esta confirmación final de su iniquidad.

En España, al igual que en gran parte de Europa, abundan los lugares donde, según se dice, poblaciones enteras fueron destruidas o hundidas en lagos por castigo divino y las zonas rurales están sembradas desde la Edad Media de pueblos abandonados por una u otra razón (Maurer 1976; Lacarra $2005)^{54}$. No faltaban otros ejemplos más recientes de castigos colectivos por

${ }^{52}$ La profesora Éva Pócs ha identificado amablemente ejemplos en el Catalogue of Hungarian Folktales, como AaTh 750A y 750B (MNK 750A Ix, MNK 750B Ix). Delpech (1988: 182) alude a relatos similares en España y al tema K 1811 (Dios o santos disfrazados visitan a los mortales) (agradezco a José Manuel Pedrosa ésta y otras referencias).

53 Salud Toledano Serrano, en conversación con Pascual Martínez, 9 de noviembre de 2010; la abuela de Salud guardaba la torta de Toribia para utilizarla en las bolsas destinadas a prevenir el mal de ojo.

${ }^{54}$ Otras historias de apariciones en España contienen episodios en los que el santo o la Virgen María castigan al vidente por no obedecer sus órdenes o no cumplir sus votos, como en Santa Gadea del Cid (1399), donde el muchacho vidente fue golpeado por unos monjes por orden de la Virgen; o en Écija (1436), donde san Pablo castigó con la mudez al muchacho vidente; en El Miracle (1458), donde los muchachos videntes murieron de peste como señal de lo que ocurriría a todos los niños; y en Cubas (1449), Jafre (1460) y El Torn (1483), localidades que fueron amenazadas con la peste si no obedecían (Christian 1990: passim). 
no recibir bien a forasteros vestidos con hábitos. En noviembre de 1875 cuando el capuchino Esteban de Andoáin (+1880) daba una misión en Lumbier (Navarra), fue apedreado en una procesión por unos jóvenes de signo liberal. Según su biografía, y lo que se cuenta aún en el pueblo, se volvió amenazante hacia ellos, y les gritó, "¡Piedras tiráis, piedras tendráis! [sic]”; y la primavera siguiente una tormenta de granizo grande como puños asoló las cosechas del pueblo (Estella 1950: 421-424) ${ }^{55}$. Una historia parecida protagonizó el agustino José López de Mendoza (1848-1923), más tarde obispo de Pamplona. Los vecinos de un pueblo de la diócesis de Osma se negaron a acudir a la misión dada por él, "y en un arranque de santa cólera, les pronosticó que pronto sentirían el castigo...”. La necrología del agustino prosigue diciendo que "la noche misma de aquel día, una horrible e inesperada tempestad preñada de granizo, asoló todos los sembrados de aquel pueblo, y nada más de aquel pueblo, dejando intactos los demás pueblos de la comarca". El autor de la necrología, otro agustino, asegura que unos años más tarde, estando él en el pueblo, se recordaba el suceso con terror y que varias personas le enseñaron por las afueras los límites donde descargó la tempestad. A raíz de este episodio la fama de López de Mendoza cundió, y cuando iba de misión la gente salía a su encuentro recelosa, preguntando: “¿Vienes de paz, o no?” (Miguélez 1923: 281-283). A la luz de todo ello, y después de la granizada devastadora ocurrida dos años antes, es posible que algunas personas de Casas de Benítez y Pozoamargo se preguntaran no sólo qué tenían que ganar si seguían las instrucciones de Toribia, sino también qué podían perder si no lo hacían.

Al tratar de las desconcertantes similitudes entre esta clase de historias en Europa y Japón, Blacker (1990: 166) conjetura si podría existir tal vez algún prototipo común más profundo y antiguo.

Un dios viajero, por ejemplo, de quien se espera que descienda de su mundo al pueblo en una estación determinada, y que exige los ritos correctos de hospitalidad y ofrendas para dispensar sus bendiciones estacionales requeridas por la población; un dios que, además, en caso de negársele esos ritos correctos, lanzará sus maldiciones contra el pueblo transgresor.

Es posible que la autora haya ido aquí demasiado lejos, pues la situación fundamental del viajero suplicante es tan común, y la idea de que los extraños pueden tener poderes especiales tan generalizada ( $\mathrm{y}$ a los caminantes les resulta tan útil cultivarla), que esos modelos tipológicos pueden surgir de manera independiente en culturas distantes. De hecho, esa venta-

${ }^{55}$ La historia me ha sido señalada por José Luis Gil Aristu, citando a su tío Valeriano Aristu Asiáin (n. 12 septiembre de 1920), quien reseña la frase del misionero y dice que, en la fecha de la maldición, granizó por un periodo de 15 años. 
josa actitud ha sido practicada desde el pasado en todas las culturas, desde el bandido Cristo y sus doce discípulos, que recorrieron la España del siglo XVI confesando y cometiendo robos (Delpech 1988), hasta los gorrones que provocaron la prohibición de los hábitos de peregrino, y los príncipes falsos, artistas fraudulentos y forasteros misteriosos descritos por Mark Twain a lo largo del Misisipí. Esa clase de imposturas prosperaron por los mismos motivos que llevaban a la gente a tener visiones de ángeles peregrinos y Cristos extraños, y a otros a creerles cuando lo decían. Como forastero de tierras lejanas que ha llamado a muchas puertas sin anunciarse, puedo dar testimonio del generoso legado de sagrada hospitalidad existente en España. Y los mendigos que bendicen y maldicen según hayan sido tratados extraen su autoridad de la misma fuente.

El ángel/peregrino, el Cristo/forastero, el ángel/joven, son seres ambiguos, a medias humanos y a medias divinos, mensajeros idóneos para transmitir órdenes celestiales. Sus visitas a Castilla la Nueva en el tiempo "real" de 1460 en Jafre, y en la década de 1930 en Casas de Benítez y Burguillos, en las tradiciones orales de Piera y Ayora y en las fabulaciones de 1727 del pastor Francisco Martínez, son ejemplos de un tipo de narración notablemente perdurable del que se han servido los españoles para relatar contactos con el cielo. En otros esquemas aparecen damas luminosas o encantadoras para impedir la peste, la santa compaña — vista todavía en Galicia-, espectros que necesitan ayuda para salir del Purgatorio, y, como en casi cualquier lugar del mundo, los muertos recientes que aportan consuelo y afecto.

Según ha mostrado Natalie Davies, estas narraciones son algo más que relatos folclóricos desencarnados situados más allá del tiempo y espacio; son pautas para ver, oír y comportarse. Estas pautas resultan a veces más evidentes cuando la versión de la vida real no concluye del todo como debiera. La "historia" está constituida por sucesos reconocibles que, una vez reconocidos, son, por tanto, documentados. Las historias de Toribia y Fausto nos hacen pensar en el valor de examinar los no sucesos — cosas que, normalmente, no fueron registradas porque no se amoldan a modelos reconocidos, en las que, por tanto, "no sucedió nada".

Y por cierto: cuando Miguel, su prima Marilina, Marisol y su marido Diego y yo fuimos a La Poza a fotografiar el lugar donde, en 1931, se reunieron las dos procesiones, llovió. (fig. 14). 


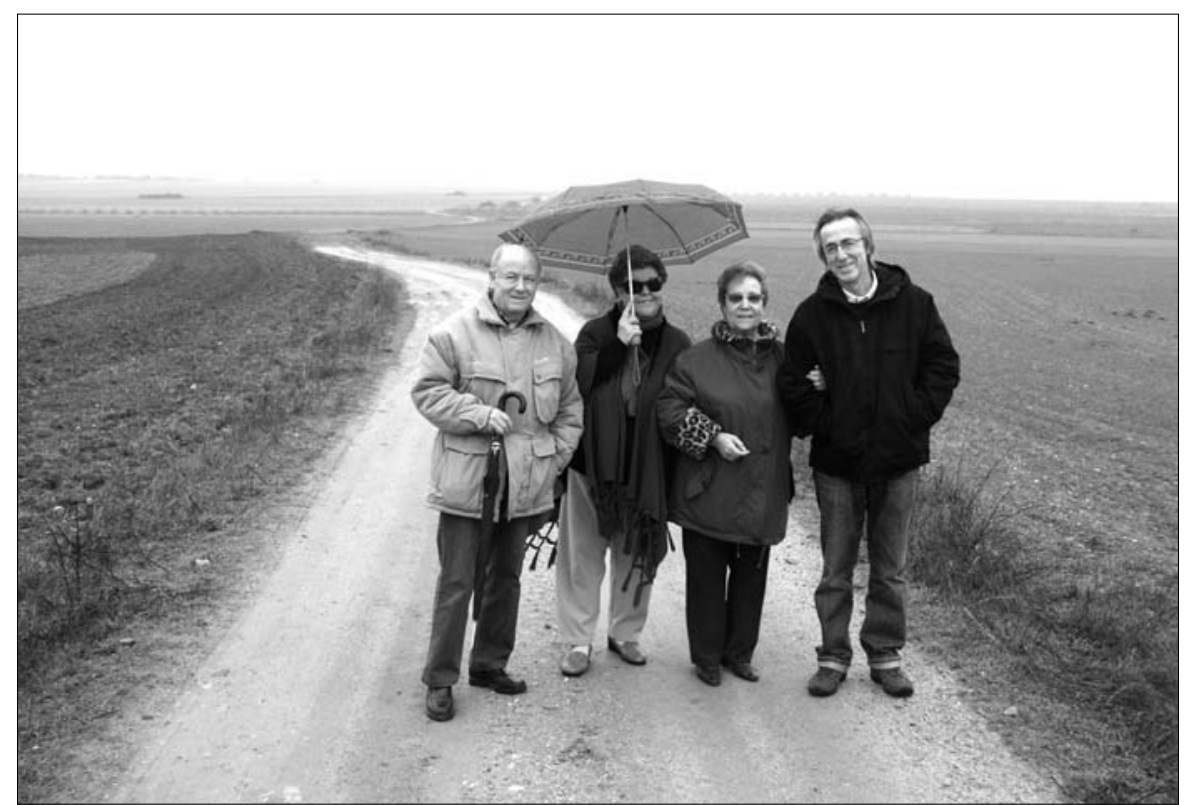

FIG. 14. Lluvia en La Poza, Casas de Benítez (Cuenca), el 8 de febrero de 2010. Foto: autor. Con permiso de los retratados.

\section{BiBLIOGRAFÍA CITADA}

Álvarez Chirveches, M. 1957. Crónica de una coronación. Cuenca 31 de Mayo 1957. Cuenca.

Bitel, L., y M. Gainer. 2009. "Looking the Wrong Way: Authenticity and Proof of Religious Visions". Visual Resources; An International Journal of Documentation 25 (1-2) (número especial doble, ed. L. Bitel, Visualizing the Invisible: Visionary Technologies in Religious and Cultural Contexts): 69-165.

Blacker, C. 1990. "The Folklore of the Stranger: A Consideration of a Disguised Wandering Saint". Folklore 101 (2): 162-68.

Caciola, N. 2003. Discerning Spirits: Divine and Demonic Possession in the Middle Ages. Cornell: Cornell University Press.

Casellas, R. 1906. "Deu-nos aigua, Majestat!", en R. Casellas, Les Multituds. Barcelona: Tobella y Costa.

Castellote Herrero, E. 2010. Libros de milagros y milagros en Guadalajara (siglos XVIXVIII). Madrid: CSIC.

Christian, W. A., Jr. 1989. "Francisco Martínez quiere ser santero. Nuevas imágenes milagrosas y su control en la España del siglo XVIII". El Folklore Andaluz 4: 103-114.

Christian, W. A., Jr. 1990. Apariciones en Castilla y Cataluña (siglos XIV-XVI). Versión revisada y ampliada de la edición inglesa de 1981, traducida por Eloy Fuente. Madrid: Nerea. 
Christian, W. A., Jr. 1991. Religiosidad local en la España de Felipe II. Versión revisada y ampliada de la edición inglesa de 1981 traducida por Javier Calzada y José Luís Gil Aristu. Madrid: Nerea.

Christian, W. A., Jr. 2009a. "Images as Beings in Early Modern Spain", en R. Kasl (ed.), Sacred Spain; Art and Belief in the Spanish World: 74-99. Indianápolis: Indianapolis Museum of Art.

Christian, W. A., Jr. 2009b. "Islands in the Sea; The Public and Private Distribution of Knowledge of Religious Visions". Visual Resources 25 (1-2): 133-65.

Christian, W. A., Jr. 2011. El Reino de Cristo en la Segunda República; una historia silenciada. Segunda ed. aumentada de Las Visiones de Ezkioga. Barcelona: Ariel.

Claret, A. M. 1852. Catecismo de la Doctrina Cristiana explicado y adaptado a la capacidad de los niños y adornado con muchas estampas. $8^{\mathrm{a}}$ ed. Barcelona: Librería Religiosa, Imprenta de Pablo Riera.

Compendio, 1833. Compendio bistórico y manual de la muy portentosa sagrada imagen del Santo Cristo de Piera y breve esplicación de lo contenido en dicha muy ilustre y antigua Villa dirigido á los devotos de tan soberana imagen. Compuesto por un devoto sacerdote. Sacado á luz á impulsos, y expensas de algunas particulares personas muy devotas de tan prodigiosa imagen á fin de aumentar más su devoción y demostrarse agradecidos á sus continuos favores y beneficios. Reimpreso en Manresa: Martín Trullás.

Cortés Peña, A. L. 1995a. "Dos siglos de rogativas en Baza (1568-1768)", en Homenaje a Antonio de Bethencourt Massieu: 455-80. Las Palmas de Gran Canaria: Ediciones del Cabildo Insular de Gran Canaria.

Cortés Peña, A. L. 1995b. "Entre la religiosidad popular y lo institucional; las rogativas en la España Moderna”. Hispania: Revista Española de Historia 55, no. 191: 1027-42.

Crémoux, F. 2001. Pèlerinages et miracles à Guadalupe au XVIe siècle. Madrid: Casa de Velázquez.

Crospis, B. 1764. Camí espayós y ample de Deu als homens, y dels homens a Deu, la Santa Imatge del Sant Christo de Piera... Sermò, que En la sua festa, dia 28. de Abril del corrent any, predicá lo M. R. P. Fr. ... Tarragona: Magì Canals.

Del Río Barreda, M. J. 2000. Madrid, Urbs Regia; la capital ceremonial de la monarquía católica. Madrid: Marcial Pons.

Delgado Ruiz, M. 1995. "Culte i profanació del Sant Crist de Piera". Miscelanea Aqualatensia (Igualada) 7: 87-114.

Delpech, F. 1988. "'Devine qui vient a diner ce soir' ou les douze aux galères; Remarques sur un Caso Notable (Gibraltar, 1592)", en A. Redondo (ed.), Les Parentés fictives en Espagne aux XVII et XVIII siècles: 167-92. París: Publications de la Sorbonne.

Díaz Hernández, M. A. (ed.) 1994. Burguillos de Toledo; las edades de un pueblo; álbum fotográfico (1865-1965). Burguillos de Toledo: Ayuntamiento de Burguillos de Toledo.

Elliott, D. 2004. Proving Woman; Female Spirituality and Inquisitional Culture in the Later Middle Ages. Princeton: Princeton University Press.

Estella, G. de. 1950. Historia y empresas apostólicas del siervo de Dios P. Esteban de Adoáin. Pamplona, Editorial Aramburu.

Faci, R. A. 1979. Aragón, Reyno de Christo y dote de María Santissima. Facsímil del libro publicado por Joseph Fort, Zarazoza, 1739, y del segundo volumen, publicado por Francisco Moreno, Zaragoza, 1750, ed. Zaragoza: La Diputación General de Aragón.

Fedele, A. 2007. "Mary Magdalene, Menstrual Blood and Mother Earth: an Anthropology of Spiritual Feminist Pilgrimages in Contemporary France and Catalonia". Tesis doc- 
toral de Filosofía no publicada, École des Hautes Études en Sciences Sociales y Universitat Autónoma de Barcelona.

Gaya Nuño, J. A. 1962. Tratado de mendicidad. Madrid: Taurus.

Gelabertó Vilagrán, M. 1991. "Tempestades y conjuros de las fuerzas naturales. Aspectos mágico-religiosos de la cultura en la alta edad moderna". Manuscrits 9: 325-44.

Gelabertó Vilagrán, M. 2005. La palabra del predicador; contrarreforma y superstición en Cataluña (siglos XVII-XVIII), Lleida: Milenio.

Gila Medina, L. 2002. Cabra del Santo Cristo (Jaén); Arte, bistoria y el Cristo de Burgos. Granada: Maracena.

Giménez de Aguilar, J. 1931. "La revolución que hay que hacer". República, Cuenca, 10 de agosto, 2.

Kamen, H. 1993. The Phoenix and the Flame; Catalonia and the Counter Reformation. New Haven: Yale University Press.

Kasl, R. (ed.) 2009. Sacred Spain; Art and Belief in the Spanish World. Indianápolis: Indianapolis Museum of Art.

Lacarra, M. J. 2005. "El Camino de Santiago en la literatura contemporánea". Boletín Hispánico Helvético 6: 141-58.

Lisón Tolosana, C. 1976. "Aspectos del pathos y ethos de la comunidad rural". Revista Española de la Opinión Pública 43: 57-72.

Llompart, G. 1967. "La llamada 'Procesión del Encuentro' en la isla de Mallorca y la filiación medieval del folklore postridentino". Revista de Dialectología y Tradiciones Populares 23: 167-180.

López, R. J. 1989. "Las rogativas públicas en Oviedo (1550-1840)". Revista de Dialectología y Tradiciones Populares 44: 187-200.

Mandrágora. 1931 "De la España fanática del siglo xx". República, Cuenca, 17 de agosto, 5 .

Marcos Arévalo, J., y E. Borrego Velásquez. 2006. "La religiosidad popular en la ciudad de Badajoz entre los siglos XVI y XVIII a partir de tres fuentes documentales; iconos religiosos, rituales de aflicción y ciclos de rogativas". Revista de Antropología Experimental. Universidad de Jaén 6: 21-42.

Martínez Martínez, P. 1982. Noticias históricas de Casas de Benítez (Cuenca). Madrid: edición personal del autor.

Martínez Martínez, P. 1996. Tradiciones y costumbres de Casas de Benitez (Cuenca). Casas de Benítez: Ayuntamiento de Casas de Benítez.

Martínez Pérez, B. 1931. "Perfiles: ...y la aldea tembló...". La Voz de Cuenca, 12 de mayo, 4.

Maurer, W. R. 1976. "German Sunken City Legends". Fabula 17: 189-214.

Miguélez, M. F. 1923. "El Rvmo. P. López, fallecido Obispo de Pamplona [1848-1923]". La Ciudad de Dios: 280-298.

Miramón, M. 1932. "Gallur: Acto civil". Vida Nueva; Órgano de la Unión General de Trabajadores y del Partido Socialista Obrero, 17 de diciembre, 3.

Pedrosa, J. M. 1999. "Calderón y la Oración del Peregrino", en Tradición oral y escrituras poéticas en los Siglos de Oro: 146-59. Oiartzun: Sendoa.

Perales, M., s.f. Memorias de la aparición de un Angel en la Villa de Ayora, extractadas del proceso instructivo formado de orden del Ilmo. Señor Don Joseph Tormo, Obispo de Orihuela, en el año 1785. Murcia: Juan Vicente Teruel, (comienzos del siglo XIX).

Pérez, N. 1947-1949. Historia Mariana De España. 5 vols. Vols. 4 y 5. Valladolid: Impresos Gerper. 
Peris Albentosa, T. 2009. "La religiosidad instrumental comunitaria en la Ribera de Júcar durante los siglos XVI-XVIII: el ejemplo de las rogativas", en A. Alberola y J. Olcina (eds.), Desastre natural, vida cotidiana y religiosidad popular en la España moderna y contemporánea: 335-89. Alicante: Universidad de Alicante.

Prat, J. 2010. "¿Por qué caminan?: Una mirada antropológica sobre el Camino de Santiago". Manuscrito sin publicar.

Premática 1590. Prematica, en que se prohibe que los naturales destos reynos no anden en abito de romeros y peregrinos: y se da orden que han de tener para yr a alguna romeria. y assi mesmo la que han de guardar los estrangeros que vinieren en romeria. Madrid: en casa de Pedro Madrigal.

Roig Torrentó, M. A, 1988. "Coexistencia de primeras advocaciones a santos locales con la nueva devoción a San Isidro Labrador (XVII-XVIII)". Boletín del Museo e Instituto Camón Aznar 33: 81-103.

Romeu Figueras, J. 1951. "Folklore de la lluvia y de las tempestades en el Pirineo catalán”. Revista de Dialectología y Tradiciones Populares 7: 292-326.

Sáez de Ocáriz y M. Ruiz de Azúa. 1990. "Climatología y régimen de lluvias en La Rioja Alta, siglos XVI al XIX". Zubia 8: 129-78.

Safford, D. 1920. "Crónica de la moda: En Palacio". ABC, 2 de abril, 9-10.

Sánchez Pérez, J. A. 1943. El culto mariano en España. Madrid: CSIC.

Sánchez-Ocaña, J. 1935. "Apariciones en Toledo; un muchacho de Burguillos dice que se le ha aparecido Jesucristo cuatro veces". Estampa, Madrid, 25 de mayo, [3-6] [11 fotografías].

Spaccarelli, T. D. 1999. A Medieval Pilgrim's Companion: Reassessing El Libro de los Huéspedes (Escorial Ms. H.I.13), North Carolina Studies in the Romance Languages and Literatures 261. Chapel Hill: University of North Carolina Press.

Spaccarelli, T. D. 2006. "La ideología de la peregrinación". Revista de Filología Románica, anexo IV: $119-27$.

Velasco, H. M. 2000. "Las leyendas de hallazgo y de singularización de imágenes marianas en España. II. Una aproximación a la categoría de imagen-persona", en D. González Cruz (ed.), Religiosidad y costumbres populares en Iberoamérica [Actas del Primer Encuentro Internacional celebrado en Almonte-El Rocío del 19 al 21 de Febrero de 1999]: 89-101. Huelva: Unversidad de Huelva.

Vilafañe, J. de. 1740. Compendio histórico en que se da noticia de las milagrosas y devotas imágenes de la Reyna de Cielo y Tierra, María Santissima. $2^{a}$ ed. Madrid: Manuel Fernández.

Viñas y Mey, C. y R. Paz. 1951, 1963. Relaciones histórico-geográfico-estadísticas de los pueblos de España hechas por iniciativa de Felipe II (Reino de Toledo). 3 vols. Madrid: CSIC.

Zamora Pastor, R. 2000. "El estudio de la sequía de principios del siglo XIX en Orihuela, a partir de los valores de las rogativas "pro pluvia"”. Investigaciones Geográficas 23: 16574

Zarco Cuevas, J. 1983. Relaciones de pueblos del Obispado de Cuenca. Cuenca: Excma. Diputación Provincial de Cuenca.

Fecha de recepción: 6 de febrero de 2011

Fecha de aceptación: 28 de julio de 2011 